\title{
Aerosol composition and sources during high and low pollution periods in Ningbo, China
}

\author{
Jing-Sha $\mathrm{Xu}^{1}$, Hong-Hui $\mathrm{Xu}^{2}$, Hang Xiao ${ }^{3,4}$, Lei Tong ${ }^{3,4}$, Colin Snape ${ }^{5}$, Cheng-Jun Wang ${ }^{6}$, \\ Jun $\mathrm{He}^{1 *}$ \\ ${ }^{1}$ International Doctoral Innovation Centre, Department of Chemical and Environmental Engineering, University \\ of Nottingham Ningbo China, Ningbo, Zhejiang, China \\ ${ }^{2}$ Zhejiang Meteorological Science Institute, Hangzhou, China \\ ${ }^{3}$ Hazardous Air Pollutants Lab, Institute of Urban Environment, Chinese Academy of Sciences, Xiamen, China \\ ${ }^{4}$ Ningbo Urban Environment Observation and Research Station-NUEORS, Chinese Academy of Sciences, \\ Ningbo, China \\ ${ }^{5}$ Faculty of Engineering, University of Nottingham, Energy Technologies Building, Triumph Road, Nottingham \\ NG7 2TU, UK \\ ${ }^{6}$ College of Chemistry and Materials Engineering, Wenzhou University, Wenzhou, China \\ *Corresponding author, Phone: 86-574-8818 9385, email: jun.he@nottingham.edu.cn
}




\section{Abstract}

2 Due to the rapid industrialization of the Yangtze River Delta (YRD) region in China, heavy 3 air pollution episodes have occurred frequently over the past five years which are of great 4 concern due to their environmental and health impacts. To investigate the chemical 5 characteristics of the highly polluted aerosols in this region, a sampling campaign had been 6 conducted in Ningbo from 3 December 2012 to 27 June 2013, during which a month long 7 high pollution episode had been captured. Daily average $\mathrm{PM}_{2.5}$ concentrations during high 8 and low pollution periods were $111 \mu \mathrm{g} \mathrm{m}^{-3}$ and $53 \mu \mathrm{g} \mathrm{m}^{-3}$, respectively. The most polluted 9 day was 8 January 2013 with a $\mathrm{PM}_{2.5}$ concentration up to $175 \mu \mathrm{g} \mathrm{m} \mathrm{m}^{-3}$. To understand the 10 origin of the highly polluted aerosols, meteorological conditions, air mass backward 11 trajectories, distribution of fire spots in surrounding areas and various categories of aerosol 12 pollutants were analysed, including trace metals, inorganic species, PAHs and anhydrosugars. 13 Total metal concentrations were 3.8 and $1.6 \mu \mathrm{g} \mathrm{m}^{-3}$ for the high and low pollution episodes, 14 respectively, accounting for $3.4 \%$ and $3.1 \%$ of the total $\mathrm{PM}_{2.5}$ mass. Total concentrations of 15 ionic species accounted for more than $50.0 \%$ of the $\mathrm{PM}_{2.5}$ by mass, with dominant ions 16 (nitrate, sulphate, ammonium) accounting for over $42.0 \%$ of the $\mathrm{PM}_{2.5}$ mass concentrations in 17 both periods. During the high pollution episode, enhanced $\mathrm{Cd}-\mathrm{Pb}$ and biomarker 18 (levoglucosan, mannosan) levels indicated the contributions from coal combustion, traffic and biomass burning to fine aerosol $\mathrm{PM}_{2.5}$. The average diagnostic ratio of $\mathrm{Fla} /(\mathrm{Fla}+\mathrm{Pyr})$ was 0.54 in high pollution episode, which was intermediate between that for wood $(>0.50)$ and coal combustion (0.58). BaP/Bpe was 0.49 and 0.30 for the highly and lightly polluted aerosols respectively, associated with the significant non-traffic emissions $(<0.60)$. In addition, stagnant weather conditions during the high pollution period and long-range transport of air masses from heavy industries and biomass burning from northern China to Ningbo could be considered as the main factors for the formation of the aerosols during high pollution period.

Keywords: aerosol, PM 2.5 , PAHs, levoglucosan, mannosan, Ningbo 


\section{Introduction}

Atmospheric aerosols can greatly affect the Earth's radiation budget and climate change along with greenhouse gases (Gkikas et al., 2016; Xin et al., 2016), and they have been verified to have significant impacts not only on visibility/haze, but also on air quality and public health, particularly those fine particles with aerodynamic diameters less than or equal to $2.5 \mu \mathrm{m}\left(\mathrm{PM}_{2.5}\right)$ (Wang et al., 2014). Highly polluted aerosols can potentially lead to lung cancer, respiratory diseases and cardiopulmonary mortality for long term exposure (Pope Iii et al., 2002; Tie et al., 2009). Generally, atmospheric aerosols can be divided into primary ones directly emitted from various sources and secondary ones formed through gas-toparticle transformation processes. In recent decades, many regions have encountered heavy aerosol pollution, including Indonesia (Field et al., 2004; Forsyth, 2014; Langmann, 2007), United States (Odman et al., 2009; Park et al., 2006; Schichtel et al., 2001), Northern Europe (Toledano et al., 2012), and China (Tao et al., 2014; Wang et al., 2015c; Zhang et al., 2015a). In China, a number of cities have experienced severe aerosol pollution with an Air Pollution Index (API) higher than 500 that is categorized as the unhealthiest level by China's Ministry of Environmental Protection (MEP). Less than 1\% of the top 500 cities in China can meet the World Health Organization air quality standards (Li and Zhang, 2014). Power plants, heavy industry and vehicles were reported to be mainly responsible for the occurrence of severe aerosol pollution episode especially in winter when domestic coal consumption increased significantly (Li and Zhang, 2014). From satellite observations, northern and eastern China was reported to be affected by hazardous dense aerosol pollution the most frequently (Tie et al., 2006). The Yangtze River Delta (YRD), located at the eastern coast of China bordering the East China Sea, has experienced many aerosol pollution events due to its remarkable economic growth and accelerated urbanization over the past 30 years (Liao et al., 2014), especially the rapid development of heavy industries, such as iron and steel, automobile manufacturing, oil and gas (Cheng et al., 2014). Additionally, another significant contributor of severe aerosol pollution in this area could be the open burning of biomass including agricultural waste which tends to be a common practice for land clearance by local farmers (Cheng et al., 2014). Previous studies have revealed high levels of aerosol pollution and extremely low visibilities in the YRD (Fu et al., 2008; Gao et al., 2011). Meteorological stations observed the average visibility of this region has shown a trend of $2.4 \mathrm{~km}$ decrease per decade from 25 to $<20 \mathrm{~km}$ in the period of $1981 \sim 2005$ (Gao et al., 2011). A few studies have been conducted to investigate the aerosol pollution episodes occurring in megacities of 
the YRD including Nanjing, Shanghai and Hangzhou (Cheng et al., 2013b; Wang et al., 2014), but non of these studies have reported detailed information on partriculate compostions.

Located at the south of YRD region, Ningbo is adjacent to Hangzhou and Shaoxing, about $15 \mathrm{~km}$ to the west coast of the East China Sea. As the second largest city of Zhejiang Province, it has a population of approximately 8 million and covers an area of around $10,000 \mathrm{~km}^{2}$. Before 2000, the number of days affected by severe aerosol pollution in Ningbo was reported to be less than 15 per year. The visibility of Ningbo ranged from 8.6 to $14.9 \mathrm{~km}$ in 1980 . However, the number of heavy aerosol pollution days was rapidly increased to 50 per year after 2001 and the visibility observed in 2003 ranged from 3.8 to $11.7 \mathrm{~km}$, which was an obvious decrease compared to that of 1980 (Cheng et al., 2013b). In January 2013, a long lasting aerosol pollution episode occurred in central and eastern China and it was considered as the most severe aerosol pollution since 2000. However, only a few studies have reported this particular event (Andersson et al., 2015; Cheng et al., 2013b; Ji et al., 2014; Wang et al., 2014). The previous studies mostly focused on the study of aerosol number concentrations, visibility, OC and EC in YRD. Only one report discussed the source apportionment of combustion-derived black carbon aerosols by using carbon isotopes (Andersson et al., 2015). Their results preliminarily show that biomass combustion contributed around $30 \%$ to the severe aerosol pollution in North China Plain (NCP, Beijing) and Yangtze River Delta (YRD, Shanghai). For black carbon, it was found that the petroleum usage and coal combustion could account for $46 \%$ and $66 \%$ of $\mathrm{BC}$ in YRD and NCP, respectively. In this study, the chemical characteristics including trace metals, ionic species, polycyclic aromatic hydrocarbons (PAHs) and biomarkers for high and low aerosol pollution periods in Ningbo have been investigated, and also diagnostic ratios, organic tracers and air mass backward trajectories have been adopted for a qualitative source analysis for this particular aerosol pollution event.

\section{Experimental}

\subsection{Sampling site and aerosol collection}

The sampling site $(29.80 \mathrm{~N}, 121.56 \mathrm{E})$ is located at the southern city of YRD- Ningbo, shown in Fig. 1(a) and (b). It is less than 10km away from the central business district (CBD). A 24hour sampling was conducted at the air monitoring station on the rooftop of Science and Engineering Building (SEB) in the University of Nottingham Ningbo Campus (UNNC) from 
93 December $3^{\text {rd }} 2012$ to June $27^{\text {th }}$ 2013, using a high volume sampler (Model: TH-1000H, 94 Tianhong Instrument CO., Ltd. Wuhan, China) with the flow rate of $1.05 \mathrm{~m}^{3} \mathrm{~min}^{-1}$. $20 \mathrm{~cm} \times 25 \mathrm{~cm}$ glass fibre filter (Huitong Instrument CO., Tianjin, China) was loaded to capture $\mathrm{PM}_{2.5}$. In total, $32 \mathrm{PM}_{2.5}$ samples were collected and blank filters were obtained every two weeks from the sampler without their pump on.

\subsection{Air mass backward trajectory and fire-spot analysis}

To investigate the effects of medium and long-range transport of aerosols on local air quality, air mass transport pathways were studied through backward trajectory analysis which was carried out using the Hybrid Single-Particle Lagrangian Integrated Trajectory (HYSPLIT) 4.9 model (Draxler, 2013; Rolph, 2013). A 4-day (96h) backward trajectory was started at the sampling site every 6 hours during each sampling day at $500 \mathrm{~m}$ above ground level (agl) and then these computed trajectories were clustered by applying TrajStat 1.2.1.0 (http://www.arl.noaa.gov/HYSPLIT.php) (Wang et al., 2009). TrajStat is a geographic information system (GIS) based software which can identify aerosol potential sources from long-term measurement data by using various trajectory statistical analysis methods. In this software, there are two clustering models- Euclidean distance and angle distance (Turpin and Huntzicker, 1995). The Euclidean distance model has been applied in this study because it concerns both the directions and distances of the trajectories while the angle distance only concerns the directions of the trajectories. In addition, Moderate Resolution Imaging Spectroradiometer (MODIS) fire-spots in this study were obtained from Fire Information for Resource Management System (FIRMS) Web Fire Mapper. Each fire-spot that was detected by satellites represents the centre of an approximately $1 \mathrm{~km}$ pixel marked as containing one or more fires, or other thermal activities.

\subsection{Chemical analysis of aerosol samples}

\subsubsection{Quality assurance and control}

Before sampling, fresh blank filters were prebaked for 4 hours at $550^{\circ} \mathrm{C}$ in a muffle furnace in order to remove any absorbed carbonaceous compounds. Equilibration of filters was carried out at constant temperature of $22^{\circ} \mathrm{C} \pm 1{ }^{\circ} \mathrm{C}$ and relative humidity $(\mathrm{RH})$ at $30 \% \pm 5 \%$ for 24 hours before and after sampling prior to gravimetric measurement by an electronic balance (Model: AL 104, Mettler Toledo, precision 0.1mg) and stored in refrigerator at $-20^{\circ} \mathrm{C}$ to avoid any possible volatilization before analysis. Four portions were cut from each filter for the analyses of trace metals, PAHs, ionic species and anhydrosugar compounds. All 
extracts were filtrated with $0.45 \mu \mathrm{m}$ pore size membranes. Calibrations were carried out by using external standard obtained from Sigma-Aldrich (St. Louis, MO, USA) and all analytical results were corrected by subtracting the values obtained from blank filters.

\subsubsection{Trace metals}

Water-extracted and acid-digested trace metals were analysed to investigate the water-soluble and total metal concentrations, respectively. Water-soluble metals were extracted ultrasonically with $15 \mathrm{~mL}$ Milli-Q water for 2.5 hours at room temperature. Total metals were extracted by $11 \mathrm{~mL}$ concentrated nitric acid (65\%, Sinopharm Chemical Reagent Co.,Ltd.) and hydrochloric acid (37\%, Sinopharm Chemical Reagent Co.,Ltd.) mixture (volume ratio 3:1) in a microwave digester (MARS 5, CEM CO., U.S.). The digestion temperature program was set as below: ramp to $185^{\circ} \mathrm{C}$ in 15 minutes and held for 25 minutes. After cooling, all extracts were filtered and further diluted with Milli-Q water to $100 \mathrm{~mL}$ and stored at $4^{\circ} \mathrm{C}$ until analysis. Water extracts were acidified by $\mathrm{HNO}_{3}$ to $2 \%$ prior to analysis. In total, 13 trace metals, including $\mathrm{Mn}, \mathrm{Zn}, \mathrm{Co}, \mathrm{Cd}, \mathrm{Cu}, \mathrm{Al}, \mathrm{Cr}, \mathrm{Ni}, \mathrm{Pb}, \mathrm{V}, \mathrm{Fe}$, Ti and As, were determined by Inductively Coupled Plasma - Mass Spectrometry (ICP-MS, NexION ${ }^{\mathrm{TM}} 300 \mathrm{X}$ ).

\subsubsection{Polycyclic aromatic hydrocarbons (PAHs)}

PAHs were extracted from filters with $20 \mathrm{~mL}$ hexane and acetone mixture (volume ratio 3:1) by a microwave digester, the conditions of which were set at: temperature $\left(50^{\circ} \mathrm{C}\right)$, microwave energy $(150 \mathrm{~W})$ and held for 20 minutes. Extracts were then filtrated and evaporated to $1 \mathrm{~mL}$ and analysed by gas chromatograph (Agilent 7890A) - mass selective detector (Agilent 5975C) (GC-MSD). GC was equipped with a capillary column (HP-5MS, $0.25 \mu \mathrm{m}$ film thickness, $30 \mathrm{~m} \times 0.25 \mathrm{~mm}$ i.d., Agilent J\&W.), using helium as carrier gas. In this study, 17 PAHs were investigated, including retene and 16 EPA priority PAHs: Naphthalene (Nap), acenaphthene (Ace), acenaphthylene (Acy), fluorene (Flu), phenanthrene (Phe), anthracene (Ant), fluoranthene (Fla), pyrene (Pyr), benzo[a]anthracene (BaA), chrysene (Chr), benzo[b]fluoranthene $(\mathrm{BbF})$, benzo[k]fluoranthene $(\mathrm{BkF})$, benzo[a]pyrene $(\mathrm{BaP})$, indeno[1,2,3-cd]pyrene (InP), dibenzo[a,h]anthracene (DBA) and benzo-[ghi]perylene (Bpe). During analysis, $1 \mu \mathrm{L}$ sample was injected in splitless mode with 5-minute solvent delay and the temperature program was set as follows (Karthikeyan et al., 2006): held at $50^{\circ} \mathrm{C}$ for 2 minutes, ramp to $200^{\circ} \mathrm{C}$ at a rate of $10^{\circ} \mathrm{C} \mathrm{min}^{-1}$ and held for 8 minutes, then ramp to $300^{\circ} \mathrm{C}$ at a rate of $5^{\circ} \mathrm{C} \mathrm{min}^{-1}$ and held for 8 minutes. PAHs were identified based on their specific $\mathrm{m} / \mathrm{z}$ at different retention time and quantified by calibration with authentic standards. 


\subsubsection{Ionic species}

Filters were extracted ultrasonically by $20 \mathrm{~mL}$ of Milli-Q water for 45 minutes and then the aqueous extracts were filtrated and stored at $4^{\circ} \mathrm{C}$ before analysis. In total, 11 inorganic ions, namely Fluoride $\left(\mathrm{F}^{-}\right)$, Chloride $\left(\mathrm{Cl}^{-}\right)$, Bromide $\left(\mathrm{Br}^{-}\right)$, Nitrate $\left(\mathrm{NO}_{3}^{-}\right)$and Sulfate $\left(\mathrm{SO}_{4}{ }^{2-}\right)$, Lithium $\left(\mathrm{Li}^{+}\right)$, Sodium $\left(\mathrm{Na}^{+}\right)$, Ammonium $\left(\mathrm{NH}_{4}^{+}\right)$, Potassium $\left(\mathrm{K}^{+}\right)$, Magnesium $\left(\mathrm{Mg}^{2+}\right)$ and Calcium $\left(\mathrm{Ca}^{2+}\right)$, were determined by Ion Chromatograph (ICS-1600). The system comprisesan autosampler (Dionex AS-DV), an analytical column (Dionex, IonPac ${ }^{\mathrm{TM}}$ AS23 for anions, IonPac $\mathrm{Pa}^{\mathrm{TM}} \mathrm{CS} 12 \mathrm{~A}$ for cations), a guard column (Dionex, IonPac ${ }^{\mathrm{TM}} \mathrm{AG} 23$ for anions, IonPac ${ }^{\mathrm{TM}}$ CG12A for cations) and a self-regenerating suppressor (Dionex, ASRS ${ }^{\mathrm{TM}}$ 300 for anions, IonPac ${ }^{\mathrm{TM}} \mathrm{CS} 12 \mathrm{~A}$ for cations). A constant eluent $\left(4.5 \mathrm{mM} \mathrm{Na} \mathrm{CO}_{3}+0.8 \mathrm{mM}\right.$ $\mathrm{NaHCO}_{3}, 1 \mathrm{~mL} \mathrm{~min}{ }^{-1}$ ) with a suppressor current at $25 \mathrm{~mA}$ were used for anion detection. Cations were investigated applying $1 \mathrm{~mL} \min ^{-1} 20 \mathrm{mM}$ Methanesulfonic acid (MSA) as eluent with a current at $59 \mathrm{~mA}$.

\subsubsection{Anhydrosugar compounds}

Filters were extracted ultrasonically by $4 \mathrm{~mL}$ Milli-Q water for 30 minutes under room temperature. The extracts then filtered and analyzed by High Performance Liquid Chromatograph (Shimadzu 30A) - Electrospray Ionisation - tandem Mass Spectrometry (ABsciex 3200 Q trap) (HPLC-ESI-MS/MS) with an anion-exchange analytical column (Dionex, Carbopac PA1, 250mm $\times 4 \mathrm{~mm}$ ) and guard column (Dionex, Carbopac PA1, $50 \mathrm{~mm} \times 4 \mathrm{~mm}$ ). Similar detection conditions can be found in the work of Piot et al. (2012) with different mobile phase. Due to the crystallization effect of sodium hydroxide solution in ion source, instead of applying $0.5 \mathrm{mM}$ sodium hydroxide solution, the mobile phase used in this study was approximately $0.5 \mathrm{mM}$ ammonium hydroxide $\left(\mathrm{NH}_{3} \cdot \mathrm{H}_{2} \mathrm{O}\right.$, HPLC level, SigmaAldrich)in isocratic mode with a flow of $0.5 \mathrm{~mL} \mathrm{~min}^{-1}$. Columns were flushed and equilibrated between two samples for 3 minutes, applying the same flow rate. Parameters of the acquisition method were optimized to achieve the best Collision Induced Dissociation efficiency with selective current of daughter ions which are $\mathrm{m} / \mathrm{z} 101+113$, and $\mathrm{m} / \mathrm{z} 101+129$ for levoglucosan (1, 6-anhydro- $\beta$-D-glucopyranose, Sigma-Aldrich) and mannosan (1, 6anhydro- $\beta$-D-mannopyranose, Sigma-Aldrich), respectively. 


\section{Results and discussion}

\subsection{Mass concentration of $\mathbf{P} \mathbf{M}_{2.5}$}

During the entire sampling period, 32 samples were collected. The temporal distribution of the daily-averaged $\mathrm{PM}_{2.5}$ concentration is plotted in Fig.2. Based on the variation of PM2.5 concentrations, the sampling period was classified as two types: high and low pollution periods. For the 18 samples collected during the winter sampling period (2012/12/032013/01/25), high ambient $\mathrm{PM}_{2.5}$ concentrations were obtained. The average $\mathrm{PM}_{2.5}$ concentration of this period is $110.9 \pm 30.8 \mu \mathrm{g} \mathrm{m}-^{3}$, much higher than the latest GB 3095 2012 Chinese "Ambient Air Quality Standard (AAQS)" Grade II standard (75.0 $\mu \mathrm{g} \mathrm{m}^{-3}$ for 24h-averaged $\mathrm{PM}_{2.5}$, applicable to residential, commercial, cultural, industrial and rural areas) (MEP, 2012). Therefore 2012/12/03-2013/01/25 was categorized as a high pollution period. For this period, the $\mathrm{PM}_{2.5}$ concentration ranged from 60.8 to $175.3 \mu \mathrm{g} \mathrm{m}^{-3}$, and the most polluted day occurred on 8 January 2013 with the highest $\mathrm{PM}_{2.5}$ concentration of $175.3 \mu \mathrm{g} \mathrm{m}$ ${ }^{3}$. This is in very good agreement with the study conducted by Wang et al. (2014) who reported the mean $\mathrm{PM}_{2.5}$ concentration in eight cities of YRD ranging from 110.8-175.6 $\mu \mathrm{g}$ $\mathrm{m}^{-3}$ in January 2013. As shown in Table 6, the average $\mathrm{PM}_{2.5}$ concentration of this study $\left(110.9 \mu \mathrm{g} \mathrm{m}^{-3}\right)$ is also comparable with that of Tianjin $\left(>94 \mu \mathrm{g} \mathrm{m}^{3}\right)$ (Han et al., 2014) in northern China, but it is much lower than the results obtained in Handan $\left(160.1 \pm 77.9 \mu \mathrm{g} \mathrm{m}^{3}\right)$ (Wei et al., 2014) and Beijing (258 $\pm 100 \mu \mathrm{g} \mathrm{m}^{3}$ ) (Ho et al., 2016) of northern China and Xi'an $\left(233 \pm 52 \mu \mathrm{g} \mathrm{m}^{-3}\right)$ (Ho et al., 2016) in central China. For the 14 samples that were collected in the remaining sampling period (2013/02/25-2013/06/27), the $\mathrm{PM}_{2.5}$ concentrations varied between 34.9 and $67.7 \mu \mathrm{g} \mathrm{m}-^{3}$ with an average of $52.6 \pm 11.9 \mu \mathrm{g} \mathrm{m}^{-3}$, which was only half of that for the high pollution period and lower than the above mentioned threshold, hence it is defined as a low pollution period accordingly.

\subsection{Meteorological conditions}

Stagnant weather conditions are favorable for the accumulation of atmospheric contaminants while flowing air is beneficial for their dispersion. In this study, meteorological data were collected from the UNNC meteorological station (WatchDog 2900ET weather station, Spectrum $^{\circledR}$ Technologies, Inc.) located at the same rooftop as the samplers. Original data (temperature, rainfall, wind speed, relative humidity) were recorded at 10-minute intervals, and were then converted to daily-averaged data and summarized in Table 1. 
217 Ningbo experiences a marine monsoon subtropical climate, featuring distinct seasons with

218 hot, humid summers and cool dry winters (Haas and Ban, 2014). This high pollution period 219 occurred in the winter in slightly windy conditions $(2.1 \mathrm{~km} / \mathrm{h})$, but the ambient temperature $220\left(6.5^{\circ} \mathrm{C}\right)$, rainfall $(0.015 \mathrm{~mm})$ and relative humidity $(67.9 \%)$ are relatively low. Under such conditions, a lower planetary boundary layer and a stronger surface inversion could be expected (Seidel et al., 2010), which would induce a more stagnant atmosphere. The low pollution period possessed had a higher average temperature $\left(18.8^{\circ} \mathrm{C}\right)$ and rainfall $(0.040 \mathrm{~mm})$, which favoured the dispersion and scavenging of aerosols.

\subsection{Air mass backward trajectory and fire-spot analysis for both high and low pollution periods}

As mentioned before, all the computed trajectories for this sampling campaign have been clustered by TrajStat model. According to the change or turning point in total spatial variance (TSV) during the Hysplit cluster analysis, 3 has been chosen as the number of clusters (Wang et al., 2015), which deems most suitable and indicative in this study by the software. After comparing the clustered results between "display means" and "display clusters", it is decided to use the statistically mean trajectory to represent the pathways of each cluster for a more concise presentation by merging through the Euclidean calculation. In Figure 3, both trajectory clustering results and fire spot data have been included; different air mass backward trajectory clusters have been presented as lines in various colours with their relative percentage shown at the left bottom of the map. Due to numerous fire-spots emerged during the sampling period (2012/12/03-2013/06/27), representative fire-spots for both periods were selected.

Fig. 3 (a) shows that the air arriving in Ningbo during the high pollution period originated from northwest direction, $60.3 \%$ of the 96 -h backward trajectories originated from northern China, and air masses transported through Hebei, Shandong and Jiangsu provinces to Ningbo. While the rest $39.7 \%$ trajectories came from Mongolia and crossed Inner Mongolia, Shanxi, Hebei, Shandong and Jiangsu provinces to the receptor site through long-range transport. During the high pollution period, trajectories were observed to pass through the north China plain with heavy industries and large farming area with plenty of fire-spots, indicating longrange contributions from industrial emission and biomass burning to the high pollution aerosols in Ningbo. 
Different from the trajectories in the high pollution period, only $17.3 \%$ of the trajectories came from Mongolia, passing through Inner Mongolia and crossing the Bo-Hai Sea and Yellow Sea to reach Ningbo, as shown in Fig. 3 (b). 42.3\% of these trajectories derived from northern China, and also travelled through the Bo-Hai Sea, Yellow Sea and East China Sea to Ningbo. While the rest 40.4\% 96-h backward trajectories originated from Taiwan and crossed the strait of Taiwan to Ningbo with a short distance.

Even though the low pollution period seemed to have slightly denser fire spot distribution than the high pollution period, as shown in Fig. 3, trajectories reaching Ningbo during low pollution period did not pass the dense fire-spots area in the northern region but were more of oceanic origins, indicating less influence of long-range transport of air pollutants including biomass burning emission to the slightly polluted aerosols in Ningbo.

\subsection{Characteristics of both high and low pollution aerosols}

\subsubsection{Trace metals}

(1) Metal concentrations

A comparison of the metal concentrations between the high and low pollution periods is listed in Table 2 which includes water soluble $(\mathrm{CWS})$ and total $\left(\mathrm{C}_{\mathrm{T}}\right)$ metal concentrations, their corresponding water solubility and enrichment factors. The sum of total metal concentrations during the high pollution episode $\left(3.8 \mu \mathrm{g} \mathrm{m}^{-3}\right)$ was approximately 2.4 times that for the low pollution period $\left(1.6 \mu \mathrm{g} \mathrm{m} \mathrm{m}^{-3}\right.$ ), accounting for $3.4 \%$ and $3.1 \%$ of total $\mathrm{PM}_{2.5}$ mass concentrations, respectively. These results in high pollution period are in good agreement with a study conducted in Beijing, which shows the sum of total 13 metal concentrations is $3.74 \mu \mathrm{g} \mathrm{m}^{-3}$, accounting for $2.6 \%$ of its total $\mathrm{PM}_{2.5}$ mass concentration (Tan et al., 2016) (Table 6). The sum of water soluble metal concentrations during high and low pollution periods were only 0.8 and $0.5 \mu \mathrm{g} \mathrm{m}^{-3}$, accounting for $0.7 \%$ and $1.0 \%$ of total $\mathrm{PM}_{2.5}$ mass concentrations, respectively. The averaged total metal abundance in the aerosol samples were in following order: $\mathrm{Al}>\mathrm{Fe}>\mathrm{Zn}>\mathrm{Mn}>\mathrm{Pb}>\mathrm{Cu}>\mathrm{As}>\mathrm{Ni}>\mathrm{Cr}>\mathrm{V}>\mathrm{Cd}>\mathrm{Ti}>\mathrm{Co}$ (High Pollution) and $\mathrm{Al}>\mathrm{Fe}>\mathrm{Zn}>\mathrm{Mn}>\mathrm{Pb}>\mathrm{Cu}>\mathrm{Ni}>\mathrm{As}>\mathrm{Cr}>\mathrm{V}>\mathrm{Ti}>\mathrm{Cd}>\mathrm{Co}$ (Low Pollution). The highest $\mathrm{Al}$ concentrations were 1.1 and $0.6 \mu \mathrm{g} \mathrm{m}^{-3}$ in the high and low pollution episodes, respectively. Compared with low pollution period, $\mathrm{Mn}, \mathrm{Co}, \mathrm{Cu}, \mathrm{As}, \mathrm{V}$ and $\mathrm{Fe}$ doubled in high pollution period. $\mathrm{Zn}$ and $\mathrm{Pb}$ were tripled, and $\mathrm{Cd}$ in high pollution episode even increased about 5 folds. The concentration of $\mathrm{Cd}$ in winter of Ningbo is $47.0 \mathrm{ng} \mathrm{m}^{-3}$, which is comparable with that in winter of a southern Chinese city- Foshan (42.6 ng m $\left.{ }^{-3}\right)$ (Tan et al., 
2014). Nevertheless, the differences of $\mathrm{Ni}$ and $\mathrm{Ti}$ between the high and low pollution periods were not as significant as those of the above mentioned others. Besides the stronger accumulation of locally emitted aerosols due to the more stagnant atmospheric condition, higher metals concentrations of $\mathrm{PM}_{2.5}$ during high pollution episode may be contributed by the long-range transport of air pollutants from heavy industries in Northern China, especially when large amount of particulates were released from coal combustion for centralized and decentralized house-heating in urban areas and countryside, respectively ( $\mathrm{Li}$ and Zhang, 2014).

\section{(2) Water solubility}

In addition to the comparison of metal concentrations between the high and low pollution samples, their water solubility was also compared. Water solubility is defined as the ratio of the water-extracted metals to the acid-extracted metals concentrations in this study. Water solubility is essential to evaluate the health effects caused by metals, because only those water-soluble fractions of metals are more likely to cause health problems due to their bioavailability (Birmili et al., 2006). In general, the water solubility varied for different metals, ranging from $8.4 \%(\mathrm{Cd})$ to $46.4 \%(\mathrm{Cu})$ in the highly polluted aerosols and $12.0 \%(\mathrm{Cd})$ to $60.3 \%(\mathrm{Cu})$ in the slightly polluted aerosols. $\mathrm{Cu}$ was found with highest solubility in both high and low pollution episodes, which could be explained that it existed dominantly as soluble salts such as sulfate in aerosol (Manousakas et al., 2014). Other metals including Ti, $\mathrm{Fe}, \mathrm{As}, \mathrm{Cr}$ and $\mathrm{Pb}$ also had moderately good water solubility $(20 \%-60 \%)$, whereas, $\mathrm{Zn}, \mathrm{Co}$, $\mathrm{Cd}$ and $\mathrm{Mn}$ were observed to have lower solubility $(<20 \%)$ in high pollution aerosols. Desboeufs et al (2005) summarized that the solubility of individual metals is related to the origins of the samples and they have found the metals in more alumino-silicated particles would be less water soluble, which may explain the lower water solubility in high pollution samples as mentioned above. It has been observed that more contributions were from longrange transported air masses to the local high pollution particles and during the transport process more aluminum containing dusts were incorporated into the aerosols in this study. Toxic metal like $\mathrm{Pb}$, with high concentrations (high pollution period $291.5 \mathrm{ng} \mathrm{m}^{-3}$, low pollution period $92.4 \mathrm{ng} \mathrm{m}^{-3}$ ) and moderately good water solubility (high pollution period $20.0 \%$, low pollution period $29.6 \%$ ) was expected to greatly influence human health. Generally, most metals were observed to have lower water solubility in the high pollution samples. Compared to the results from other studies conducted in East China (Hsu et al., 2010; Jiang et al., 2014), the water solubility of $\mathrm{Cu}, \mathrm{Pb}, \mathrm{V}$ and As were in good agreement; 
however, the water solubility of $\mathrm{Cd}$ and $\mathrm{Zn}$ in highly polluted samples in this study were lower than the reported data, while Fe and $\mathrm{Ti}$ of both periods showed higher water solubility than those collected in Hong Kong (Jiang et al., 2014). In addition to the various extraction methods applied, the particular aerosol matrix affected by diverse yet distinct sources in different studied areas may result in the discrepancy of recovery efficiency of individual metals.

\section{(3) Enrichment factor}

The enrichment factors (EFs) can be applied to investigate whether the metals were originated from anthropogenic or natural sources. $\mathrm{EF}$ of each metal $\left(\mathrm{EF}_{\mathrm{i}}\right)$ in this study was calculated by dividing the relative abundance of each metal in a $\mathrm{PM}_{2.5}$ sample by its corresponding average abundance in the upper continental crust and it was normalized by a commonly used reference metal- Al, which was chosen due to its stability in chemical analysis (Birmili et al., 2006; Zhou et al., 2014). The calculation is carried out by the following equation (1) (Zhou et al., 2014):

$\mathrm{EF}_{\mathrm{i}}=\left(\frac{\mathrm{C}_{\mathrm{i}}}{\mathrm{C}_{\mathrm{ref}}}\right)_{\text {atmosphere }} /\left(\frac{\mathrm{C}_{\mathrm{i}}}{\mathrm{C}_{\mathrm{ref}}}\right)_{\text {crust }}$

Where, $\left(\mathrm{C}_{\mathrm{i}} / \mathrm{C}_{\text {ref }}\right)_{\text {atmosphere }}$ is the ratio of specified metal $\left(\mathrm{C}_{\mathrm{i}}\right)$ and reference metal $\left(\mathrm{C}_{\mathrm{ref}}\right)$ concentrations in aerosol samples, while $\left(\mathrm{C}_{\mathrm{i}} / \mathrm{C}_{\mathrm{ref}}\right)_{\text {crust }}$ is the ratio of specified metal $\left(\mathrm{C}_{\mathrm{i}}\right)$ and reference metal $\left(\mathrm{C}_{\mathrm{ref}}\right)$ concentration in the upper continental crust. Metal concentrations in upper continental crust were $6.62 \%$ for $\mathrm{Al}, 2.94 \%$ for $\mathrm{Fe}, 0.38 \%$ for $\mathrm{Ti}$ and $583,74.2,12.7$, 0.097, 22.6, 61, 26.9, 26, 11.2 and $82.4 \mathrm{mg} \mathrm{kg}^{-1}$ for $\mathrm{Mn}, \mathrm{Zn}, \mathrm{Co}, \mathrm{Cu}, \mathrm{Cr}, \mathrm{Ni}, \mathrm{Pb}, \mathrm{As}$ and $\mathrm{V}$, respectively, reported by China's National Environmental Monitoring Centre (CNEMC) (CNEMC, 1990).

In this study, most metals have EF values greater than 10, suggesting their primarily anthropogenic sources, such as vehicles and industrial emissions (Zhou et al., 2014). However, the $\mathrm{EF}$ value of $\mathrm{Fe}$ is only 1.7 and 1.2 in high and low pollution samples, respectively. This might be because $\mathrm{Fe}$ has the second highest crustal background concentration $\left(\mathrm{C}_{\mathrm{Fe}}\right)_{\text {crust }}$ which have led to relatively lower $\mathrm{EF}$ value, even though the concentration of Fe ranked the second in all metals. It is noteworthy that $\mathrm{EF}$ value of $\mathrm{Ti}$ is less than 1, which indicates $\mathrm{Ti}$ is depleted in the environment and crustal sources are dominant. Mn, Co, $\mathrm{Cr}$ and $\mathrm{V}$ were found moderately enriched $(10<\mathrm{EF}<100)$, implying majority of them were emitted from human activities. Toxic As was found to have consistently high EF (>100) values in both high and low pollution samples, as well as $\mathrm{Zn}, \mathrm{Cu}$, 
$\mathrm{Pb}, \mathrm{Ni}$ and $\mathrm{Cd}$, suggesting they were all significantly related with anthropogenic sources. The mean $\mathrm{EF}$ value of them are ranked as: $\mathrm{Cd}>\mathrm{Pb}>\mathrm{Zn}>\mathrm{As}>\mathrm{Cu}>\mathrm{Ni}$, which showed very good agreement with the atmospheric metal study carried in Foshan that the top five EF values were in the same order and $\mathrm{Cd}$ even had the highest daily maximum EF value of 18,357.0 (Tan et al., 2014). The EF value of Cd in this study is 29, 509.0 (haze), which is nearly 3.2 times to the low pollution period $(9,269.6)$. The $\mathrm{EF}$ of $\mathrm{Pb}$ in high pollution period (648.8) shows approximately 1.6 times higher than that of low pollution period (397.7). The EF value of $\mathrm{Zn}$ in high pollution period (604.1) increased by a factor of 1.9 compared to low pollution period (318.1). While the $\mathrm{EF}$ value of $\mathrm{Ni}$ and $\mathrm{Ti}$ were reversely higher in low pollution period. Higher EF values of metals during high pollution period imply that cool and dry winter with less rainfall favored the accumulation of these metals onto particles in addition to those greatly contributed by long-range transport from north China.

(4) Correlations among trace metals

Correlations among trace metals can be used to determine whether these metals have similar sources, therefore, the correlation coefficients of each trace metal for both high and low pollution periods are summarized in Table 3 . In low pollution period, there are no significant correlations between metals. Nevertheless, few metals were observed to have good correlations in high pollution period. $\mathrm{V}, \mathrm{Fe}, \mathrm{Ti}, \mathrm{Cr}, \mathrm{Mn}$ and $\mathrm{As}$ have high correlation coefficients $(0.72<\mathrm{r}<0.95)$. As is characterized as one of the representatives of coal burning in China (Kang et al., 2011). V is released to the ambient environment from oil burning and the fossil fuel combustion is reported to account for $85 \%$ of total $\mathrm{V}$ emissions in China (Duan and Tan, 2013). The correlated V, Fe, Ti, Cr, Mn and As may suggest that oil burning and coal combustion could be the major sources of these metals. The ratio of $\mathrm{Cu} / \mathrm{As}$ was reported to be $1.2(279 / 224$, ug/g in PM) in honeycomb coal burning (Ge et al., 2004), while in this study it is approximately 1.8 during the high pollution period, indicating coal combustion may not be the unique source of $\mathrm{Cu}$, and worn tires and automobile brake pads abrasion particles could be another contributors of $\mathrm{Cu}$ (Okuda et al., 2008). $\mathrm{Cd}$ and $\mathrm{Pb}$, which were reported to correlate in coal-fired power plants in China (Deng et al., 2014), were also found with a significant correlation coefficient of 0.9581 in the high pollution period. As reported by $\mathrm{Ge}$ et al. (2004) and Karanasiou et al. (2007), $\mathrm{Cd}$ and $\mathrm{Pb}$ existed predominantly in fine particles other than in coarse particles of coal burning, part of aerosols containing $\mathrm{Cd}$ and $\mathrm{Pb}$ could be possibly transported from Northern China (as shown in Fig. 3 (a)), where heavy industries and centralized / decentralized house-heating are responsible for coal emissions. 


\subsubsection{Polycyclic aromatic hydrocarbons (PAHs)}

PAHs are usually predominantly derived from incomplete combustion or high-temperature pyrolysis processes of fossil fuels and biomass (Ravindra et al., 2008). The average concentrations of each PAH during the high and low pollution periods are plotted in Fig.4. The total PAH concentration during the high pollution episode ranged from 15.2 to $331.9 \mathrm{ng}$ $\mathrm{m}^{-3}$ with an average of $90.6 \mathrm{ng} \mathrm{m}^{-3}$, accounting for $0.8 \%$ of total $\mathrm{PM}_{2.5}$ mass concentration. These results are comparable with those in other cities (Nantong, Wuxi and Suzhou) of YRD (range: 13.9-229.0 $\mathrm{ng} \mathrm{m}^{-3}$, average: $88.2 \mathrm{ng} \mathrm{m}^{-3}$ ) (Zhang et al., 2013). As seen in Table 6, the average total PAH concentration in this study is also consistent with the result in PRD (91.5 \pm $36.1 \mathrm{ng} \mathrm{m}^{-3}$ ) (Huang et al., 2014), but lower than the result in Zhengzhou of northern China, which is $211 \mathrm{ng} \mathrm{m}^{-3}$ and accounts for $1.2 \%$ of total $\mathrm{PM}_{2.5}$ mass concentration (Wang et al., 2015a). The total PAHs level in the low pollution episode ranged from 14.3 to 59.6 with an average of $34.8 \mathrm{ng} \mathrm{m}^{-3}$. Results in this work were higher than the PAHs concentrations obtained in Guangzhou (low pollution period: $13.3 \mathrm{ng} \mathrm{m}^{-3}$, high pollution period: $59.8 \mathrm{ng} \mathrm{m}^{-3}$ ) (Tan et al., 2011). Compared to the low pollution episode, BkF, Flu, Chr, Bpe, BbF, BaA, $\mathrm{BaP}$ and InP were about tripled, while Phe, Ant, Ace, Fla, Pyr and Bpe were about doubled and the rest pollutants increased less than $50 \%$. In addition to the strong accumulation of local aerosols and long-range transport of those from outside of this region, another reason for higher occurrence levels of PAHs during the high pollution period (winter time) could be due to the relatively lower temperature which would promote more PAHs to distribute and condense onto particulate matter via the gas-particle partitioning process $(\mathrm{He}$ and Balasubramanian, 2009).

During the high pollution episode $\mathrm{BkF}, \mathrm{BbF}, \mathrm{InP}$, Bpe and $\mathrm{Chr}$ dominated. BkF exhibited the highest concentration at $13.3 \mathrm{ng} \mathrm{m}^{-3}$ and Acy was the lowest at $0.017 \mathrm{ng} \mathrm{m}^{-3}$ in high pollution aerosols. The concentration of highly carcinogenic $\mathrm{BaP}$ was $3.8 \mathrm{ng} \mathrm{m}^{-3}$ during the high pollution episode, similar to the result in northeast China (Jin et al., 2012). Retene has been identified as a tracer for soft wood burning especially conifers (Azevedo et al., 2002) and its concentration was doubled during the high pollution period, indicating the increased contribution from soft wood burning.

The low molecular weight 2 and3 ring PAHs - Nap, Ace, Acy, Flu and Ant, were observed in low abundance in particle phases $\left(<1 \mathrm{ng} \mathrm{m}^{-3}\right)$, while the high molecular weight PAHs (4-6 rings) accounted for $87.5 \%$ of total PAHs. This result is in good agreement with the study conducted in Nanjing where 4-6 ring PAHs accounted for more than $80 \%$ of the total PAHs 
411 (Meng et al., 2015). Basically, PAHs with 2 or 3 rings are present mainly in gaseous phase 412 due to their higher volatility and they would more actively participate in photochemical reactions and, thus, their atmospheric lifetimes are reported to be a few hours or less, much shorter than those with more than three rings (Oliveira et al., 2014).

The diagnostic ratios of PAHs in particulates have been commonly used as indicators for source apportionment of PAHs (Bourotte et al., 2005; Esen et al., 2008; Harrison et al., 1996). Previous studies have shown that PAH concentrations varied largely based on their composition and different emission sources (Alves et al., 2014), therefore, some PAH ratios are adopted to study the source origins. The mean value of Fla/(Fla+Pyr) during the high pollution episode ranged from 0.32 to 0.70 , with an average value of 0.54 , which was in the range of wood combustion $(>0.50)$, approaching 0.58 for coal combustion (Bravo-Linares et al., 2012; $\mathrm{Xu}$ et al., 2012). The diagnostic ratio of $\mathrm{BaP} / \mathrm{Bpe}$ was calculated at 0.49 and 0.30 for the high and low pollution aerosols respectively, associated with the result of non-traffic emissions $(<0.6)$ (Bravo-Linares et al., 2012), indicating less influence of traffic on PAH concentrations and $\mathrm{PM}_{2.5}$ concentrations. This is reasonable since the sampling site is around half kilometre away from the main roads where the air pollution attributed to traffic emissions could be reduced to low levels (Zhu et al., 2002). To summarize, aerosols were not significantly influenced by traffic emissions, mainly arising from pyrogenic sources, such as biomass burning and coal combustion.

\subsubsection{Inorganic ions}

The ion concentrations, their relative abundance in $\mathrm{PM}_{2.5}$ and their ratios for the high and low pollution episodes are summarized in Table 4. Total ionic mass concentrations in the high and low pollution periods were 59.5 and $32.6 \mu \mathrm{g} \mathrm{m}^{-3}$, accounting for $55.3 \%$ and $62.0 \%$ of $\mathrm{PM}_{2.5}$ mass concentrations, respectively. As compared in Table 6, the total ionic mass concentration during high pollution period in this study $\left(59.5 \mu \mathrm{g} \mathrm{m}^{-3}, 55.3 \%\right.$ in $\left.\mathrm{PM}_{2.5}\right)$ is higher than that of Hangzhou in YRD (41.7 $\mu \mathrm{g} \mathrm{m}^{-3}, 38.5 \%$ in $\left.\mathrm{PM}_{2.5}\right)$ (Liu et al., 2015), but lower than that of Handan in northern China (77.3 $\mu \mathrm{g} \mathrm{m}^{-3}, 48.3 \%$ in $\mathrm{PM}_{2.5}$ ) (Wei et al., 2014). Sulfate, nitrate and ammonium (namely SNA) ranked as top three ions in the high pollution period and their total concentration reached up to $45.2 \mu \mathrm{g} \mathrm{m}^{-3}$, accounting for $78.0 \%$ of total ions masses and $42.0 \%$ of $\mathrm{PM}_{2.5}$ mass, repsectively. This result was in good agreement with the studies conducted in Nanjing, Hangzhou and Shanghai of YRD, which have shown that SNA accounting for $41.0-61.0 \%$ of $\mathrm{PM}_{2.5}$ (Fu et al., 2008). Furthermore, the result is also comparable with two studies conducted in Beijing of northern China with SNA accounting 
for $35.8 \%$ and $45.2 \%$ of $\mathrm{PM}_{2.5}$ (Tan et al., 2016, Ho et al., 2016). Nevertheless, the result in this study is slighltly lower compared with that of Xi'an in central China, which has shown that SNA contributed to $53.9 \%$ of total $\mathrm{PM}_{2.5}$ concentration (Ho et al., 2016). In low pollution aerosols, the abundance of sulfate, nitrate and ammonium accounted for even higher percentage $(44.0 \%)$ of aerosols with total average concentration of $23.2 \mu \mathrm{g} \mathrm{m}^{-3}$, accounting for $71.3 \%$ of total ions masses. Similar result was also found in Chengdu where sulfate, nitrate and ammonium accounted for $72.9 \%$ of total ion concentration (Tao et al., 2013). When comparing them individually, $\mathrm{SO}_{4}{ }^{2-}$ and $\mathrm{NO}_{3}{ }^{-}$were doubled in high pollution period, while $\mathrm{NH}_{4}{ }^{+}$was about 2.7 times higher. In low pollution episode, $\mathrm{SO}_{4}{ }^{2-}, \mathrm{NO}_{3}{ }^{-}, \mathrm{NH}_{4}{ }^{+}$and $\mathrm{K}^{+}$ were obviously decreased, especially $\mathrm{NH}_{4}{ }^{+}$which decreased from $7.2 \mu \mathrm{g} \mathrm{m}^{-3}$ (High Pollution) to $2.7 \mu \mathrm{g} \mathrm{m}^{-3}$ (Low Pollution), while the rest ions such as $\mathrm{Na}^{+}$was not significantly changed.

Since the sampling site is located in an international port city- Ningbo, marine contribution to ionic species needs to be eliminated to evaluate the inputs from other sources in this study. Measured $\mathrm{Na}^{+}$was assumed to be derived from sea salts. Non-sea salt (nss) components were calculated using the following equation (2) (Kong et al., 2014):

nss-X $=\mathrm{X}_{\mathrm{i}}-\mathrm{Na}^{+}{ }_{\mathrm{i}} \times\left(\mathrm{X} / \mathrm{Na}^{+}\right)_{\text {sea }}$

where, $X_{i}$ represents the ion concentration in samples, $\mathrm{Na}^{+}{ }_{i}$ is the concentration of $\mathrm{Na}^{+}$in sample and $\left(\mathrm{X} / \mathrm{Na}^{+}\right)$sea is seawater ratio which is 0.0385 for $\mathrm{Ca}^{2+}, 0.037$ for $\mathrm{K}^{+}$and 0.2516 for $\mathrm{SO}_{4}{ }^{2-}$ respectively based on seawater composition (Balasubramanian et al., 2003). For the

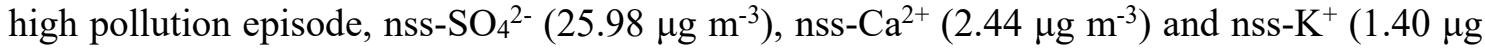
$\mathrm{m}^{-3}$ ) accounted for $95.7 \%, 93.3 \%$ and $89.2 \%$ of $\mathrm{SO}_{4}{ }^{2-}, \mathrm{Ca}^{2+}$ and $\mathrm{K}^{+}$mass respectively. As for

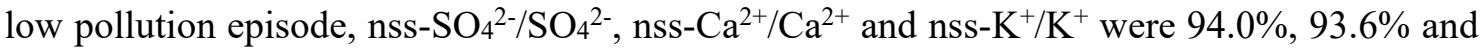
$83.4 \%$ respectively, similar to high pollution aerosols. These results indicated that marine sources are not the dominant origin of these ions. The mass ratio of $\mathrm{Na}^{+} / \mathrm{SO}_{4}{ }^{2-}$ is 0.17 and 0.24 in the high and low pollution samples, repsectively, much lower than that of seawater (3.98), reconfirming that marine source was not pridominant (Yuan et al., 2015). The high value of nss- $\mathrm{Ca}^{2+} / \mathrm{Ca}^{2+}$ indicate a large amount of continental contribution to atmospheric $\mathrm{Ca}^{2+}$. A few studies have revealed $\mathrm{K}^{+}$is a tracer of biomass burning (Chow et al., 2004). Two times higher nss- $\mathrm{K}^{+}$was observed in the high pollution episode compared with low pollution episode. This is not surprising since the air in high pollution episode passed through the region with more dense fire-spots than low pollution episode, which could have carried more biomass burning pollution to affect the sampling site. Further investigation on biomass burning impact on local air quality would be discussed in section 3.4.4. 
Other than marine-derived sulfate and nitrate, these ions may also be formed through gasparticle transition. Therefore, to investigate the transformation of $\mathrm{SO}_{2}$ to $\mathrm{SO}_{4}{ }^{2-}$ and $\mathrm{NO}_{2}$ to $\mathrm{NO}_{3}^{-}$, sulfur oxidation ratio (SOR) and nitrogen oxidation ratio (NOR) were applied and caculated by following equations (Lin, 2002):

$\mathrm{SOR}=\left[\mathrm{nss}_{-} \mathrm{SO}_{4}{ }^{2-}\right] /\left(\left[\mathrm{nss}^{-\mathrm{SO}_{4}}{ }^{2-}\right]+\left[\mathrm{SO}_{2}\right]\right)$

$\mathrm{NOR}=\left[\mathrm{NO}_{3}^{-}\right] /\left(\left[\mathrm{NO}_{3}^{-}\right]+\left[\mathrm{NO}_{2}\right]\right)$

Where $[X]$ refers to molar concentration, higher value of SOR and NOR would imply the greater oxidation of gaseous species like $\mathrm{SO}_{2}$ and $\mathrm{NO}_{2}$ and the increase of secondary aerosol formation. In this work, NOR in high and low pollution episodes were 0.14 and 0.08 respectively, indicating the formation of nitrate during the high pollution episode, which is consistent with the result obtained in Shanghai where the NOR value was 0.18 and 0.084 during high and low pollution days respectively (Hua et al., 2015). It is reported that the photochemical oxidation of $\mathrm{SO}_{2}$ occurred when $\mathrm{SOR}>0.1$ (Ohta and Okita, 1990). The SOR value for the low pollution episode was 0.44 , suggesting a considerable conversion from $\mathrm{SO}_{2}$ to $\mathrm{SO}_{4}{ }^{2-}$. While the $\mathrm{SOR}$ value for the high pollution samples $(0.27)$ was surprisingly lower than that of low pollution samples, but comparable with the SOR values of high pollution aerosols in Taiwan (0.30) and Guangzhou (0.29) (Lin, 2002; Tan et al., 2009). Lower SOR in high pollution aerosols may probably due to the rapid increase of $\mathrm{SO}_{2}$ and relatively less formation of sulphate during high pollution episode: (1) During the high pollution episode, with more stagnant weather during the winter at Ningbo, more $\mathrm{SO}_{2}$ would preferably accumulate under poorer air circulation/ dispersion and weaker solar radiation. (2) Additionally, it has also reported that high $\mathrm{NO}_{2}$ concentrations and weak photochemical process cannot generate sufficient oxidants for the formation of sulphate (Hua et al., 2008). The ratio of $\left(\mathrm{NO}_{3}{ }^{-} / \mathrm{nss}-\mathrm{SO}_{4}{ }^{2-}\right)$ to $\left(\mathrm{NO}_{2} / \mathrm{SO}_{2}\right)$ in high pollution aerosols was more than 4 times higher than low pollution aerosols, suggesting nitrate formation is more significant than sulphate formation in high pollution episode. The higher formation of nitrate may have hindered the generation of conversion oxidants for the formation of sulphate and consequently led to lower SOR value in high pollution period.

In this study, the correlation between $\mathrm{NH}_{4}^{+}$and $\mathrm{SO}_{4}{ }^{2-}$ was only 0.12 during the low pollution episode, while $\mathrm{NH}_{4}^{+}$was highly correlated with $\mathrm{NO}_{3}^{-}$with coefficient of 0.70 , indicating nitrate dominated in secondary inorganic aerosols formation in low pollution episode. In high pollution aerosols, $\mathrm{NH}_{4}^{+}$was found both highly correlated with $\mathrm{SO}_{4}{ }^{2-}$ and $\mathrm{NO}_{3}^{-}$with 
coefficients of 0.72 and 0.73 respectively, indicating the formation of $\left(\mathrm{NH}_{4}\right)_{2} \mathrm{SO}_{4}, \mathrm{NH}_{4} \mathrm{HSO}_{4}$ and $\mathrm{NH}_{4} \mathrm{NO}_{3}$, which is consistent with the results in Shanghai during high pollution period (Du et al., 2011). The correlation coefficients between SOR and NOR-temprature were 0.31 and 0.08 , indicating very little influence of temprature. No obvious relation was obseved between SOR, NOR and relative humidity. The correlation coefficients between SOR, NOR and $\mathrm{PM}_{2.5}$ concentrations were 0.16 and 0.42 , repsectively, indicating higher aerosol concentration (higher surface area) may have potentially favored the secondary aerosol formation though the number concentrations have not been considered here.

\subsubsection{Anhydrosugar compounds}

Anhydrosugars such as levoglucosan (L) and mannosan (M) are reported as unique and stable components of aerosols emitted from biomass burning (Saarnio et al., 2010), thus, they are used as tracers to investigate contributions from biomass burning to high pollution aerosols in this study. The average concentrations of levoglucosan and mannosan during high and low pollution episodes are listed in Table 5, as well as the ratio of $\mathrm{L}$ and $\mathrm{M}$. The average concentrations of levoglucosan during dry high pollution episode and wet low pollution period were $76.1 \pm 27.7 \mathrm{ng} \mathrm{m}^{-3}$ and $14.7 \pm 6.7 \mathrm{ng} \mathrm{m}^{-3}$, accounting for $0.7 \%$ and $0.3 \%$ of total $\mathrm{PM}_{2.5}$ mass concentration, respectively. Compared with the results above, a suburb area located in Pearl River Delta (PRD) region of south China was observed with higher concentration of levoglucosan during dry season $\left(181.0 \pm 124.0 \mathrm{ng} \mathrm{m}^{-3}\right)$ but with a lower concentration during the wet season $\left(7.5 \pm 8.7 \mathrm{ng} \mathrm{m}^{-3}\right)$ (Zhang et al., 2015b). As shown in Table 6, significantly higher levoglucosan concentrations were observed in Beijing of Northern China and Xi'an of Central China than in this study. In Beijing the average levoglucosan concentrations are reported to be $307 \mathrm{ng} \mathrm{m}^{-3}$ (3.1\%o in $\mathrm{PM}_{2.5}$ ) (Zhang et al., 2008 ) and $359.3 \pm 130.2 \mathrm{ng} \mathrm{m}^{-3}$ (1.4\%o in $\mathrm{PM}_{2.5}$ ) (Ho et al., 2016), while in Xi'an even higher level of levoglucosan is found at $653.3 \pm 191.4 \mathrm{ng} \mathrm{m}^{-3}$ and accounting for $2.8 \%$ of $\mathrm{PM}_{2.5}$ mass concentration (Ho et al., 2016). Significantly higher concentrations of levoglucosan in northern and central China could be possibly due to large amount of softwood/grass burning for decentralized house-heating in the country area especially during the winter season (Cheng et al., 2013a). The average concentration of mannosan in this study during the dry high pollution episode $\left(14.9 \pm 6.3 \mathrm{ng} \mathrm{m}^{-3}\right)$ was about 5 fold higher compared to the wet low pollution episode $\left(2.6 \pm 1.4 \mathrm{ng} \mathrm{m}^{-3}\right)$. The concentration of mannosan during the dry high pollution episode was comparable with that of dry season in PRD region $\left(10.0 \pm 6.2 \mathrm{ng} \mathrm{m}^{-3}\right)$ (Zhang et al., 2015b). Higher levoglucosan and mannosan concentrations in the high 
542 pollution aerosols indicated the strong contribution from biomass burning to the organic matter present. In this study, levoglucosan was correlated very well with mannosan, with coefficient of 0.99 and both of them were positively correlated to $\mathrm{PM}_{2.5}$, with linear coefficients of 0.67 and 0.60 , respectively, further confirming that biomass burning contributed to the high pollution aerosols.

The $\mathrm{L} / \mathrm{M}$ ratios can also be used to distinguish emissions from specific types of biomass. Based on combustion chamber studies, Engling et al. (2013) summarized the following L/M ratios for the differentiation of various biomass sources: softwood (3-5), hard wood (14-15), peat (11) and grass (5.5). In addition, Sang et al. (2013) reported average L/M ratios were $32.6 \pm 19.1$ for crop residues. In this study, the high pollution episode has displayed a consistent $\mathrm{L} / \mathrm{M}$ ratio with average of 5.2, while $\mathrm{L} / \mathrm{M}$ of low pollution episode is in between of 4.8 and 7.2, with average of 5.9, which falls into the L/M range of softwood and grass burning. Given that the high pollution episode occurred from December 2012 to January 2013 when rice harvest season had passed in YRD, it might be safe to infer that rice straw burning was not the dominant form of biomass burning. Based on the air mass backward trajectory analysis, long-range transport of these organic tracers from north China might be the main origin where the softwood/grass in addition to coal would be used in large amounts for decentralized heating in the country area (Cheng et al., 2013a).

\section{Conclusions}

1. For the 32 samples analysed, the high pollution samples clearly exhibited a higher average concentration of $\mathrm{PM}_{2.5}\left(111 \mu \mathrm{g} \mathrm{m}^{-3}\right)$ than the low pollution samples $\left(53 \mu \mathrm{g} \mathrm{m}^{-3}\right)$.

2. High pollution aerosols had higher concentrations of metals, PAHs, inorganic ions and organic tracers. Total ionic mass concentrations in the high and low pollution periods were 59.5 and $32.6 \mu \mathrm{g} \mathrm{m}^{-3}$, respectively, accounting for $55.3 \%$ and $62.0 \%$ of $\mathrm{PM}_{2.5}$ mass concentrations, respectively, with nitrate, sulphate and ammonium accounting for over $42.0 \%$ of $\mathrm{PM}_{2.5}$ mass concentrations in both periods. Total metals concentrations were $3.8 \mu \mathrm{g} \mathrm{m}^{-3}$ and $1.6 \mu \mathrm{g} \mathrm{m}^{-3}$ in the high and low pollution episodes respectively. Al was the highest in both episodes. PAHs in Ningbo were comparable with those in other cities of YRD. The high molecular weight PAHs (4-6 rings) accounted for $87.5 \%$ of total PAHs.

3. Heavy metals including $\mathrm{Cd}$ and $\mathrm{Pb}$ indicated that there is a major contribution from anthropogenic sources especially from coal combustion. Diagnostic ratios Fla/(Fla+Pyr) and $\mathrm{BaP} / \mathrm{Bpe}$ indicated the predominant sources of PAHs were both coal and wood combustion, 
574 rather than traffic emissions. The elevated nss- $\mathrm{K}^{+}$, retene, levoglucosan and mannosan 575 concentrations, and the ratio of $\mathrm{L} / \mathrm{M}$ around 5 during the high pollution episode implied 576 contributions from softwood and grass burning to the aerosols.

577 4. Through the comparisons of above mentioned chemical components in highly polluted 578 aerosols between this study and other studies in China, those medium-sized and megacities in 579 Northern and Central China seemed to be experiencing generally more severe aerosol 580 pollution than in YRD region in terms of the occurrence levels of $\mathrm{PM}_{2.5}$, PAHs, inorganic 581 ions and biomass burning tracer levoglucosan for the past decade.

582 5. Long-range trajectories showed that the air in Ningbo during the high pollution episode 583 had been transported from heavily polluted northern areas and passed through regions with 584 more dense fire spots than the low pollution episode. To summarize, the high pollution 585 aerosols in Ningbo arise from a combination of local emissions, long-range transport of air 586 pollution and formation of secondary aerosols with the assistance of stagnant atmospheric 587 conditions in this region.

\section{Acknowledgements}

589 The authors acknowledge the financial support from the International Doctoral Innovation 590 Centre, Ningbo Education Bureau, Ningbo Science and Technology Bureau, China's MoST 591 and The University of Nottingham. This work was also partially supported by Natural 592 Science Foundation of China (41303091), Zhejiang Provincial Applied Research Program for 593 Commonweal Technology (2015C33011), Strategic Priority Research Program (B) of the 594 Chinese Academy of Sciences (XDB05020403), Ningbo Municipal Natural Science 595 Foundation (2014A610096), Ningbo Municipal Key Project (2012B10042) and Open Fund 596 by Jiangsu Key Laboratory of AEMPC (KHK1304 \& KHK1204). 


\section{Reference}

Alves, N.d.O., Hacon, S.d.S., de Oliveira Galvao, M.F., Peixotoc, M.S., Artaxo, P., Vasconcellos, P.d.C., Batistuzzo de Medeiros, S.R., 2014. Genetic damage of organic matter in the Brazilian Amazon: A comparative study between intense and moderate biomass burning. Environ. Res. 130, 51-58.

Andersson, A., Deng, J., Du, K., Zheng, M., Yan, C., Skold, M., Gustafsson, O., 2015. Regionally-Varying Combustion Sources of the January 2013 Severe Haze Events over Eastern China. Environ. Sci. Technol. 49, 2038-2043.

Azevedo, D.D., dos Santos, C.Y.M., Neto, F.R.D., 2002. Identification and seasonal variation of atmospheric organic pollutants in Campos dos Goytacazes, Brazil. Atmos. Environ. 36, 2383-2395.

Balasubramanian, R., Qian, W.B., Decesari, S., Facchini, M.C., Fuzzi, S., 2003. Comprehensive characterization of $\mathrm{PM}_{2.5}$ aerosols in Singapore. J. Geophys. Res.: Atmos. 108.

Birmili, W., Allen, A.G., Bary, F., Harrison, R.M., 2006. Trace metal concentrations and water solubility in size-fractionated atmospheric particles and influence of road traffic. Environ. Sci. Technol. 40, 11441153.

Bourotte, C., Forti, M.C., Taniguchi, S., Bicego, M.C., Lotufo, P.A., 2005. A wintertime study of PAHs in fine and coarse aerosols in Sao Paulo city, Brazil. Atmos. Environ. 39, 3799-3811.

Bravo-Linares, C., Ovando-Fuentealba, L., Mudge, S.M., Cerpa, J., Loyola-Sepulveda, R., 2012. Source Allocation of Aliphatic and Polycyclic Aromatic Hydrocarbons in Particulate-Phase (PM10) in the City of Valdivia, Chile. Polycyclic Aromatic Compounds. 32, 390-407.

Cheng, Y., Engling, G., He, K.B., Duan, F.K., Ma, Y.L., Du, Z.Y., Liu, J.M., Zheng, M., Weber, R.J., $2013 a$. Biomass burning contribution to Beijing aerosol. Atmos. Chem. Phys. 13, 7765-7781.

Cheng, Z., Wang, S., Fu, X., Watson, J.G., Jiang, J., Fu, Q., Chen, C., Xu, B., Yu, J., Chow, J.C., Hao, J., 2014. Impact of biomass burning on haze pollution in the Yangtze River delta, China: a case study in summer 2011. Atmos. Chem. Phys. 14, 4573-4585.

Cheng, Z., Wang, S., Jiang, J., Fu, Q., Chen, C., Xu, B., Yu, J., Fu, X., Hao, J., 2013b. Long-term trend of haze pollution and impact of particulate matter in the Yangtze River Delta, China. Environ. Pollut. 182, 101110.

Chow, J.C., Watson, J.G., Kuhns, H., Etyemezian, V., Lowenthal, D.H., Crow, D., Kohl, S.D., Engelbrecht, J.P., Green, M.C., 2004. Source profiles for industrial, mobile, and area sources in the Big Bend Regional Aerosol Visibility and Observational study. Chemosphere. 54, 185-208.

CNEMC, 1990. The Background Values of Chinese Soils. China National Environmental Monitoring Centre, Environmental Science Press of China, Beijing. 1-370 (in Chinese).

Deng, S., Shi, Y.J., Liu, Y., Zhang, C., Wang, X.F., Cao, Q., Li, S.G., Zhang, F., 2014. Emission characteristics of $\mathrm{Cd}, \mathrm{Pb}$ and $\mathrm{Mn}$ from coal combustion: Field study at coal-fired power plants in China. Fuel Process. Technol. 126, 469-475.

Desboeufs, K.V., Sofikitis, A., Losno, R., Colin, J.L., Ausset, P., 2005. Dissolution and solubility of trace metals from natural and anthropogenic aerosol particulate matter. Chemosphere. 58, 195-203.

Draxler, R.R.a.R., G.D., 2013. HYSPLIT (HYbrid Single-Particle Lagrangian Integrated Trajectory) Model access via NOAA ARL READY Website (http://ready.arl.noaa.gov/HYSPLIT.php). NOAA Air Resources Laboratory, Silver Spring, MD.

Du, H., Kong, L., Cheng, T., Chen, J., Du, J., Li, L., Xia, X., Leng, C., Huang, G., 2011. Insights into summertime haze pollution events over Shanghai based on online water-soluble ionic composition of aerosols. Atmos. Environ. 45, 5131-5137.

Duan, J., Tan, J., 2013. Atmospheric heavy metals and Arsenic in China: Situation, sources and control policies. Atmos. Environ. 74, 93-101.

Engling, G., Lee, J.J., Sie, H.-J., Wu, Y.-C., Yet-Pole, I., 2013. Anhydrosugar characteristics in biomass smoke aerosol-case study of environmental influence on particle-size of rice straw burning aerosol. J. Aerosol Sci. 56, 2-14.

Esen, F., Tasdemir, Y., Vardar, N., 2008. Atmospheric concentrations of PAHs, their possible sources and gasto-particle partitioning at a residential site of Bursa, Turkey. Atmos. Res. 88, 243-255.

Field, R.D., Wang, Y., Roswintiarti, O., Guswanto, 2004. A drought-based predictor of recent haze events in western Indonesia. Atmos. Environ. 38, 1869-1878.

Forsyth, T., 2014. Public concerns about transboundary haze: A comparison of Indonesia, Singapore, and Malaysia. Glob. Environ. Chang. 25, 76-86.

Fu, Q., Zhuang, G., Wang, J., Xu, C., Huang, K., Li, J., Hou, B., Lu, T., Streets, D.G., 2008. Mechanism of formation of the heaviest pollution episode ever recorded in the Yangtze River Delta, China. Atmos. Environ. 42, 2023-2036. 
Gao, L., Jia, G.S., Zhang, R.J., Che, H.Z., Fu, C.B., Wang, T.J., Zhang, M.G., Jiang, H., Van, P., 2011. Visual Range Trends in the Yangtze River Delta Region of China, 1981-2005. J. Air Waste Manage. Assoc. 61, 843-849.

Ge, S., Xu, X., Chow, J.C., Watson, J., Sheng, Q., Liu, W.L., Bai, Z.P., Zhu, T., Zhang, J.F., 2004. Emissions of air pollutants from household stoves: Honeycomb coal versus coal cake. Environ. Sci. Technol. 38, 4612-4618.

Gkikas, A., Hatzianastassiou, N., Mihalopoulos, N., Torres, O., 2016. Characterization of aerosol episodes in the greater Mediterranean Sea area from satellite observations (2000-2007). Atmos. Environ. 128, 286-304

Haas, J., Ban, Y.F., 2014. Urban growth and environmental impacts in Jing-Jin-Ji, the Yangtze, River Delta and the Pearl River Delta. Int. J. Appl. Earth Obs. Geoinf. 30, 42-55.

Han, S.-q., Wu, J.-h., Zhang, Y.-f., Cai, Z.-y., Feng, Y.-c., Yao, Q., Li, X.-j., Liu, Y.-w., Zhang, M., 2014. Characteristics and formation mechanism of a winter haze-fog episode in Tianjin, China. Atmos. Environ. 98, 323-330.

Harrison, R.M., Smith, D.J.T., Luhana, L., 1996. Source apportionment of atmospheric polycyclic aromatic hydrocarbons collected from an urban location in Birmingham, UK. Environ. Sci. Technol. 30, 825832.

He, J., Balasubramanian, R., 2009. A study of gas/particle partitioning of SVOCs in the tropical atmosphere of Southeast Asia. Atmos. Environ. 43, 4375-4383.

Ho, K.-F., Ho, S.S.H., Huang, R.-J., Chuang, H.-C., Cao, J.-J., Han, Y., Lui, K.-H., Ning, Z., Chuang, K.-J., Cheng, T.-J., Lee, S.-C., Hu, D., Wang, B., Zhang, R., 2016. Chemical composition and bioreactivity of $\mathrm{PM}_{2.5}$ during 2013 haze events in China. Atmos. Environ. 126, 162-170.

Hsu, S.-C., Wong, G.T.F., Gong, G.-C., Shiah, F.-K., Huang, Y.-T., Kao, S.-J., Tsai, F., Lung, S.-C.C., Lin, F.J., Lin, I.I., Hung, C.-C., Tseng, C.-M., 2010. Sources, solubility, and dry deposition of aerosol trace elements over the East China Sea. Mar. Chem. 120, 116-127.

Hua, W., Chen, Z.M., Jie, C.Y., Kondo, Y., Hofzumahaus, A., Takegawa, N., Chang, C.C., Lu, K.D., Miyazaki, Y., Kita, K., Wang, H.L., Zhang, Y.H., Hu, M., 2008. Atmospheric hydrogen peroxide and organic hydroperoxides during PRIDE-PRD'06, China: their concentration, formation mechanism and contribution to secondary aerosols. Atmos. Chem. Phys. 8, 6755-6773.

Hua, Y., Cheng, Z., Wang, S., Jiang, J., Chen, D., Cai, S., Fu, X., Fu, Q., Chen, C., Xu, B., Yu, J., 2015. Characteristics and Source Apportionment of $\mathrm{PM}_{2.5}$ during a Fall Heavy Haze Episode in the Yangtze River Delta of China. Atmos. Environ. 123, 380-391.

Huang, B., Liu, M., Bi, X., Chaemfa, C., Ren, Z., Wang, X., Sheng, G., Fu, J., 2014. Phase distribution, sources and risk assessment of PAHs, NPAHs and OPAHs in a rural site of Pearl River Delta region, China. Atmos. Pollut. Res. 5, 210-218.

Ji, D., Li, L., Wang, Y., Zhang, J., Cheng, M., Sun, Y., Liu, Z., Wang, L., Tang, G., Hu, B., Chao, N., Wen, T., Miao, H., 2014. The heaviest particulate air-pollution episodes occurred in northern China in January, 2013: Insights gained from observation. Atmos. Environ. 92, 546-556.

Jiang, S.Y.N., Yang, F., Chan, K.L., Ning, Z., 2014. Water solubility of metals in coarse PM and $\mathrm{PM}_{2.5}$ in typical urban environment in Hong Kong. Atmos. Pollut. Res. 5, 236-244.

Jin, G., Cong, L., Fang, Y., Li, J., He, M., Li, D., 2012. Polycyclic aromatic hydrocarbons in air particulates and its effect on the Tumen river area, Northeast China. Atmos. Environ. 60, 298-304.

Kang, Y., Liu, G., Chou, C.-L., Wong, M.H., Zheng, L., Ding, R., 2011. Arsenic in Chinese coals: Distribution, modes of occurrence, and environmental effects. Sci. Total Environ. 412-413, 1-13.

Karanasiou, A.A., Sitaras, I.E., Siskos, P.A., Eleftheriadis, K., 2007. Size distribution and sources of trace metals and n-alkanes in the Athens urban aerosol during summer. Atmos. Environ. 41, 2368-2381.

Karthikeyan, S., Balasubramanian, R., See, S.W., 2006. Optimization and validation of a low temperature microwave-assisted extraction method for analysis of polycyclic aromatic hydrocarbons in airborne particulate matter. Talanta. 69, 79-86.

Kong, S., Wen, B., Chen, K., Yin, Y., Li, L., Li, Q., Yuan, L., Li, X., Sun, X., 2014. Ion chemistry for atmospheric size-segregated aerosol and depositions at an offshore site of Yangtze River Delta region, China. Atmos. Res. 147, 205-226.

Langmann, B., 2007. A model study of smoke-haze influence on clouds and warm precipitation formation in Indonesia 1997/1998. Atmos. Environ. 41, 6838-6852.

Li, M., Zhang, L., 2014. Haze in China: Current and future challenges. Environ. Pollut. 189, 85-86.

Liao, J.B., Wang, T.J., Wang, X.M., Xie, M., Jiang, Z.Q., Huang, X.X., Zhu, J.L., 2014. Impacts of different urban canopy schemes in WRF/Chem on regional climate and air quality in Yangtze River Delta, China. Atmos. Res. 145, 226-243.

Lin, J.J., 2002. Characterization of water-soluble ion species in urban ambient particles. Environ. Int. 28, 55-61. Liu, G., Li, J., Wu, D., Xu, H., 2015. Chemical composition and source apportionment of the ambient $\mathrm{PM}_{2.5}$ in Hangzhou, China. Particuology. 18, 135-143. 
Manousakas, M., Papaefthymiou, H., Eleftheriadis, K., Katsanou, K., 2014. Determination of water-soluble and insoluble elements in $\mathrm{PM}_{2.5}$ by ICP-MS. Sci. Total Environ. 493, 694-700.

Meng, Q., Fan, S., He, J., Zhang, J., Sun, Y., Zhang, Y., Zu, F., 2015. Particle size distribution and characteristics of polycyclic aromatic hydrocarbons during a heavy haze episode in Nanjing, China. Particuology. 18, 127-134.

MEP, Chinese Ministry of Environmental Protection, 2012. Ambient Air Quality Standards (GB3095-2012).

Odman, M.T., Hu, Y., Russell, A.G., Hanedar, A., Boylan, J.W., Brewer, P.F., 2009. Quantifying the sources of ozone, fine particulate matter, and regional haze in the Southeastern United States. J. Environ. Manage. 90, 3155-3168.

Ohta, S., Okita, T., 1990. A chemical characterization of atmospheric aerosol in Sapporo. Atmos. Environ. Part A. General Topics. 24, 815-822.

Okuda, T., Katsuno, M., Naoi, D., Nakao, S., Tanaka, S., He, K., Ma, Y., Lei, Y., Jia, Y., 2008. Trends in hazardous trace metal concentrations in aerosols collected in Beijing, China from 2001 to 2006. Chemosphere. 72, 917-924.

Oliveira, R.L., Loyola, J., Minho, A.S., Quiterio, S.L., Azevedo, D.d.A., Arbilla, G., 2014. PM 2.5 -Bound Polycyclic Aromatic Hydrocarbons in an Area of Rio de Janeiro, Brazil Impacted by Emissions of Light-Duty Vehicles Fueled by Ethanol-Blended Gasoline. Bull. Environ. Contam. Toxicol. 93, 781786.

Park, R.J., Jacob, D.J., Kumar, N., Yantosca, R.M., 2006. Regional visibility statistics in the United States: Natural and transboundary pollution influences, and implications for the Regional Haze Rule. Atmos. Environ. 40, 5405-5423.

Piot, C., Jaffrezo, J.L., Cozic, J., Pissot, N., El Haddad, I., Marchand, N., Besombes, J.L., 2012. Quantification of levoglucosan and its isomers by High Performance Liquid Chromatography - Electrospray Ionization tandem Mass Spectrometry and its applications to atmospheric and soil samples. Atmos. Meas. Tech. 5, 141-148.

Pope Iii, C.A., Burnett, R.T., Thun, M.J., Calle, E.E., Krewski, D., Ito, K., Thurston, G.D., 2002. Lung cancer, cardiopulmonary mortality, and long-term exposure to fine particulate air pollution. J. Am. Medical. Assoc. 287, 1132-1141.

Ravindra, K., Sokhi, R., Van Grieken, R., 2008. Atmospheric polycyclic aromatic hydrocarbons: Source attribution, emission factors and regulation. Atmos. Environ. 42, 2895-2921.

Rolph, G.D., 2013. Real-time Environmental Applications and Display sYstem (READY) Website (http://ready.arl.noaa.gov). NOAA Air Resources Laboratory, Silver Spring, MD. .

Saarnio, K., Teinila, K., Aurela, M., Timonen, H., Hillamo, R., 2010. High-performance anion-exchange chromatography-mass spectrometry method for determination of levoglucosan, mannosan, and galactosan in atmospheric fine particulate matter. Anal. Bioanal. Chem. 398, 2253-2264.

Sang, X., Zhang, Z., Chan, C., Engling, G., 2013. Source categories and contribution of biomass smoke to organic aerosol over the southeastern Tibetan Plateau. Atmos. Environ. 78, 113-123.

Schichtel, B.A., Husar, R.B., Falke, S.R., Wilson, W.E., 2001. Haze trends over the United States, 1980-1995. Atmos. Environ. 35, 5205-5210.

Seidel, D.J., Ao, C.O., Li, K., 2010. Estimating climatological planetary boundary layer heights from radiosonde observations: Comparison of methods and uncertainty analysis. J. Geophys. Res.: Atmos. 115.

Tan, J., Duan, J., He, K., Ma, Y., Duan, F., Chen, Y., Fu, J., 2009. Chemical characteristics of PM 2.5 during a typical haze episode in Guangzhou. J. Environ. Sci. 21, 774-781.

Tan, J., Duan, J., Ma, Y., Yang, F., Cheng, Y., He, K., Yu, Y., Wang, J., 2014. Source of atmospheric heavy metals in winter in Foshan, China. Sci. Total Environ. 493, 262-270.

Tan, J., Duan, J., Zhen, N., He, K., Hao, J., 2016. Chemical characteristics and source of size-fractionated atmospheric particle in haze episode in Beijing. Atmos. Res. 167, 24-33.

Tan, J., Guo, S., Ma, Y., Duan, J., Cheng, Y., He, K., Yang, F., 2011. Characteristics of particulate PAHs during a typical haze episode in Guangzhou, China. Atmos. Res. 102, 91-98.

Tao, J., Zhang, L., Engling, G., Zhang, R., Yang, Y., Cao, J., Zhu, C., Wang, Q., Luo, L., 2013. Chemical composition of $\mathrm{PM}_{2.5}$ in an urban environment in Chengdu, China: Importance of springtime dust storms and biomass burning. Atmos. Res. 122, 270-283.

Tao, M., Chen, L., Xiong, X., Zhang, M., Ma, P., Tao, J., Wang, Z., 2014. Formation process of the widespread extreme haze pollution over northern China in January 2013: Implications for regional air quality and climate. Atmos. Environ. 98, 417-425.

Tie, X., Brasseur, G.P., Zhao, C., Granier, C., Massie, S., Qin, Y., Wang, P., Wang, G., Yang, P., Richter, A., 2006. Chemical characterization of air pollution in Eastern China and the Eastern United States. Atmos. Environ. 40, 2607-2625.

Tie, X., Wu, D., Brasseur, G., 2009. Lung cancer mortality and exposure to atmospheric aerosol particles in Guangzhou, China. Atmos. Environ. 43, 2375-2377. 
Toledano, C., Cachorro, V.E., Gausa, M., Stebel, K., Aaltonen, V., Berjón, A., Ortiz de Galisteo, J.P., de Frutos, A.M., Bennouna, Y., Blindheim, S., Myhre, C.L., Zibordi, G., Wehrli, C., Kratzer, S., Hakansson, B., Carlund, T., de Leeuw, G., Herber, A., Torres, B., 2012. Overview of sun photometer measurements of aerosol properties in Scandinavia and Svalbard. Atmos. Environ. 52, 18-28.

Turpin, B.J., Huntzicker, J.J., 1995. Identification of secondary organic aerosol episodes and quantitation of primary and secondary organic aerosol concentrations during SCAQS. Atmos. Environ. 29, 3527-3544.

Wang, H., An, J., Shen, L., Zhu, B., Pan, C., Liu, Z., Liu, X., Duan, Q., Liu, X., Wang, Y., 2014. Mechanism for the formation and microphysical characteristics of submicron aerosol during heavy haze pollution episode in the Yangtze River Delta, China. Sci. Total Environ. 490, 501-508.

Wang, J., Li, X., Jiang, N., Zhang, W., Zhang, R., Tang, X., 2015a. Long term observations of PM 2.5 -associated PAHs: Comparisons between normal and episode days. Atmos. Environ. 104, 228-236.

Wang, L., Liu, Z., Sun, Y., Ji, D., Wang, Y., 2015b. Long-range transport and regional sources of $\mathrm{PM}_{2.5}$ in Beijing based on long-term observations from 2005 to 2010. Atmos. Res. 157, 37-48.

Wang, M., Cao, C., Li, G., Singh, R.P., 2015c. Analysis of a severe prolonged regional haze episode in the Yangtze River Delta, China. Atmos. Environ. 102, 112-121.

Wang, Y.Q., Zhang, X.Y., Draxler, R.R., 2009. TrajStat: GIS-based software that uses various trajectory statistical analysis methods to identify potential sources from long-term air pollution measurement data. Environ. Modell. Softw. 24, 938-939.

Wei, Z., Wang, L.T., Chen, M.Z., Zheng, Y., 2014. The 2013 severe haze over the Southern Hebei, China: $\mathrm{PM}_{2.5}$ composition and source apportionment. Atmos. Pollut. Res. 5, 759-768.

Xin, J., Gong, C., Wang, S., Wang, Y., 2016. Aerosol direct radiative forcing in desert and semi-desert regions of northwestern China. Atmos. Res. 171, 56-65.

Xu, L., Zheng, M., Ding, X., Edgerton, E.S., Reddy, C.M., 2012. Modern and Fossil Contributions to Polycyclic Aromatic Hydrocarbons in $\mathrm{PM}_{2.5}$ from North Birmingham, Alabama in the Southeastern U.S. Environ. Sci. Technol. 46, 1422-1429.

Yuan, Q., Li, W., Zhou, S., Yang, L., Chi, J., Sui, X., Wang, W., 2015. Integrated evaluation of aerosols during haze-fog episodes at one regional background site in North China Plain. Atmos. Res. 156, 102-110.

Zhang, L., Zhang, T., Dong, L., Shi, S., Zhou, L., Huang, Y., 2013. Assessment of halogenated POPs and PAHs in three cities in the Yangtze River Delta using high-volume samplers. Sci. Total Environ. 454-455, 619-626.

Zhang, Q., Quan, J., Tie, X., Li, X., Liu, Q., Gao, Y., Zhao, D., 2015a. Effects of meteorology and secondary particle formation on visibility during heavy haze events in Beijing, China. Sci. Total Environ. 502, 578-584.

Zhang, T., Claeys, M., Cachier, H., Dong, S., Wang, W., Maenhaut, W., Liu, X., 2008. Identification and estimation of the biomass burning contribution to Beijing aerosol using levoglucosan as a molecular marker. Atmos. Environ. 42, 7013-7021.

Zhang, Z., Gao, J., Engling, G., Tao, J., Chai, F., Zhang, L., Zhang, R., Sang, X., Chan, C.-y., Lin, Z., Cao, J., 2015b. Characteristics and applications of size-segregated biomass burning tracers in China's Pearl River Delta region. Atmos. Environ. 102, 290-301.

Zhou, S., Yuan, Q., Li, W., Lu, Y., Zhang, Y., Wang, W., 2014. Trace metals in atmospheric fine particles in one industrial urban city: Spatial variations, sources, and health implications. J. Environ. Sci.: China. 26, 205-213.

Zhu, Y., Hinds, W.C., Kim, S., Sioutas, C., 2002. Concentration and Size Distribution of Ultrafine Particles Near a Major Highway. J. Air Waste Manage. Assoc. 52, 1032-1042. 


\section{$822 \quad$ Figure Captions}

823 Fig. 1 (a) Location of YRD region in China and (b) Location of Ningbo in YRD

824 Fig. 2 Daily-averaged $\mathrm{PM}_{2.5}$ concentrations during the high and low pollution periods of 825 Ningbo from $2012 / 12 / 03$ to $2013 / 06 / 27$

826 Fig. 3 Air mass backward trajectories and representative fire spots during the (a) high and (b) 827 low pollution periods in Ningbo

828 Fig. 4 Comparison of PAH concentrations in the high and low pollution periods 


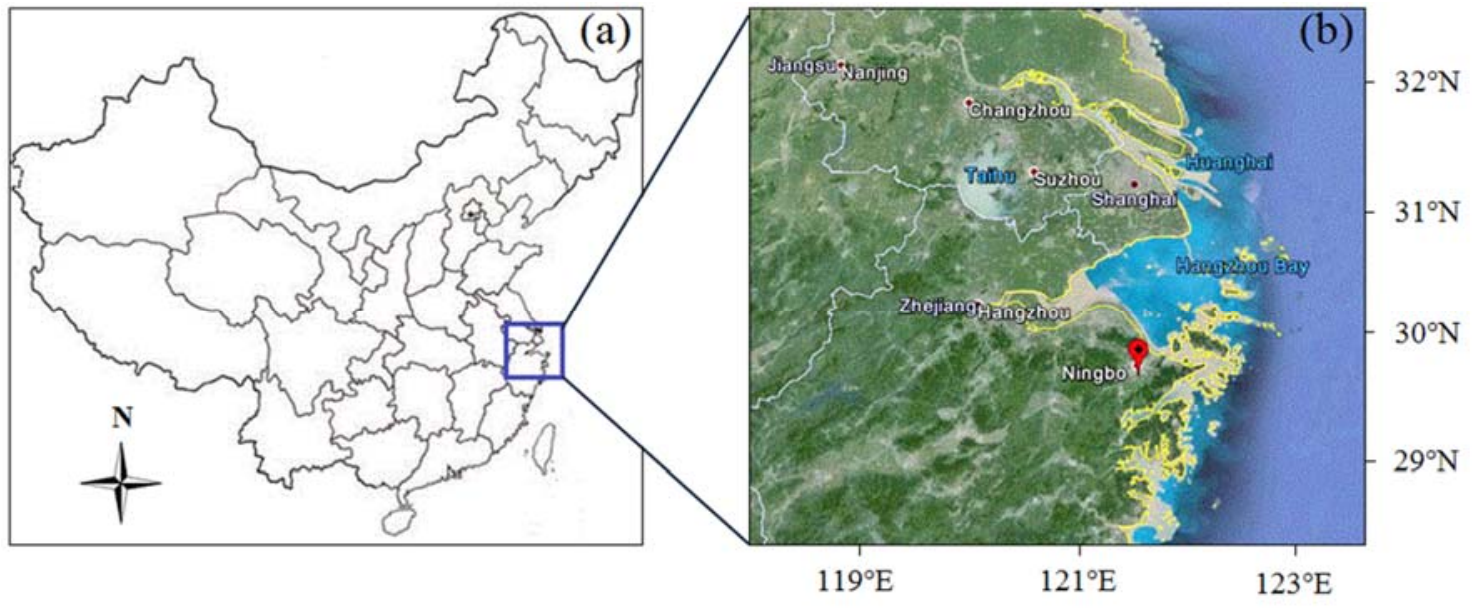

829

830

Fig. 1 (a) Location of YRD region in China and (b) Location of Ningbo in YRD 


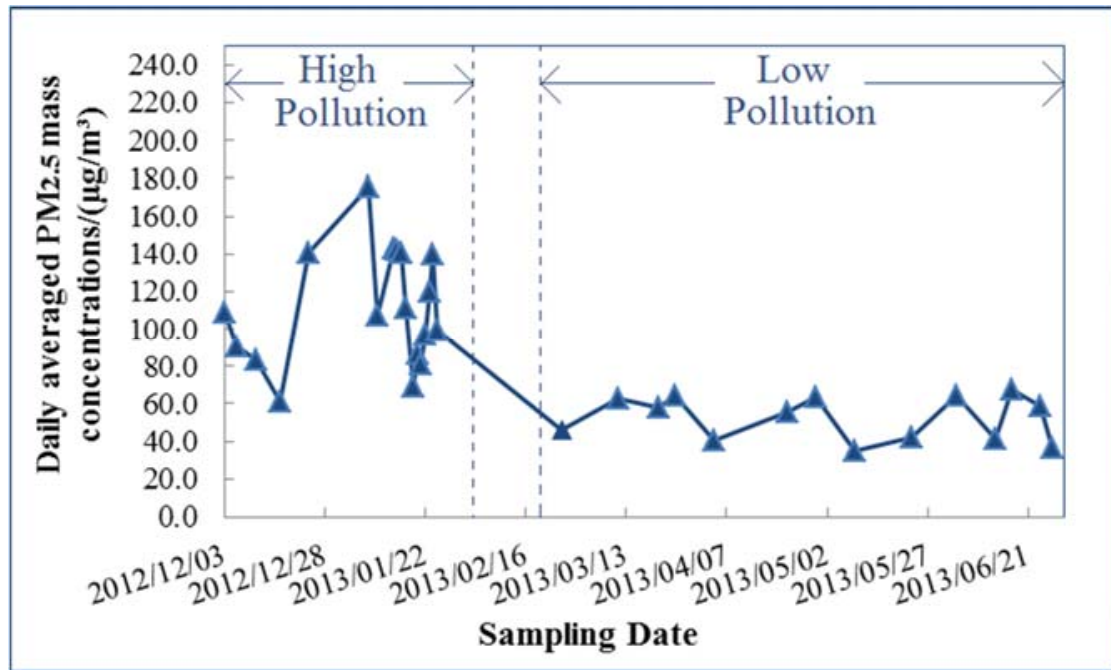

833

Fig. 2 Daily-averaged $\mathrm{PM}_{2.5}$ concentrations during the high and low pollution periods of Ningbo from

$2012 / 12 / 03$ to $2013 / 06 / 27$ 

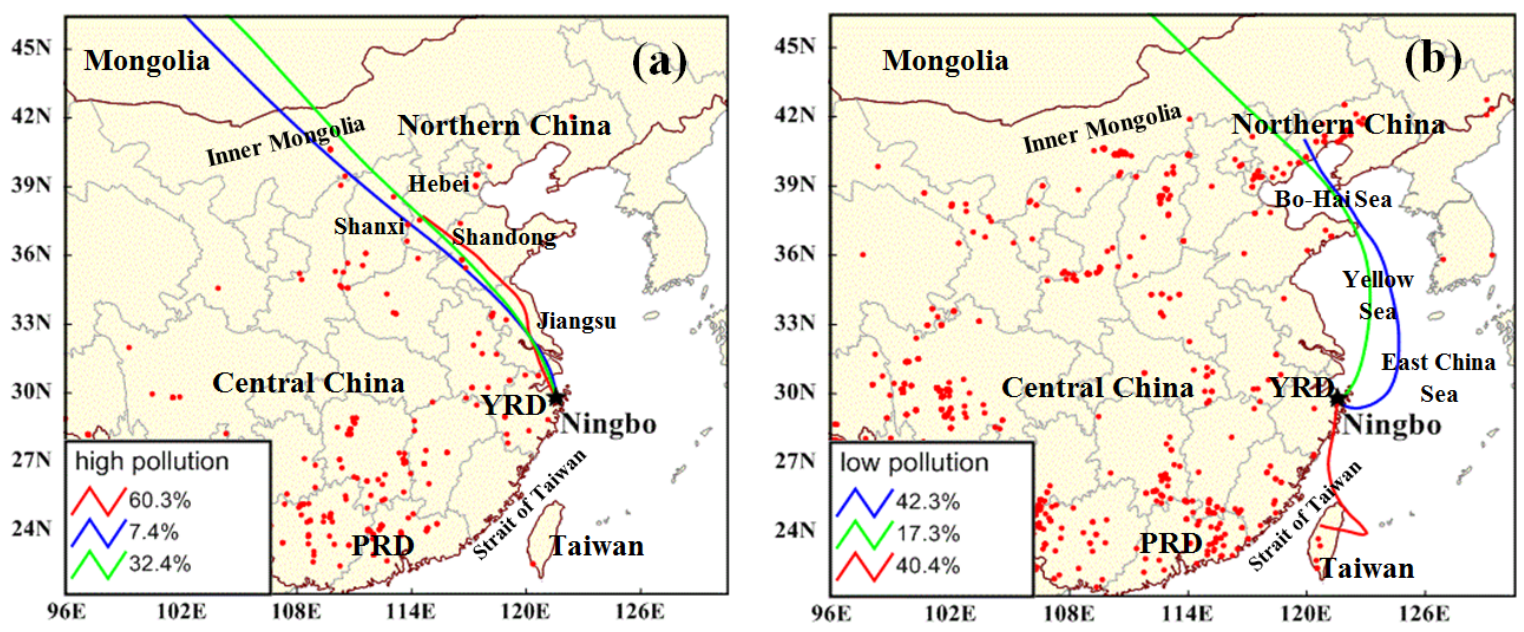

836

Fig. 3 Air mass backward trajectories and representative fire spots during the (a) high and (b) low pollution 


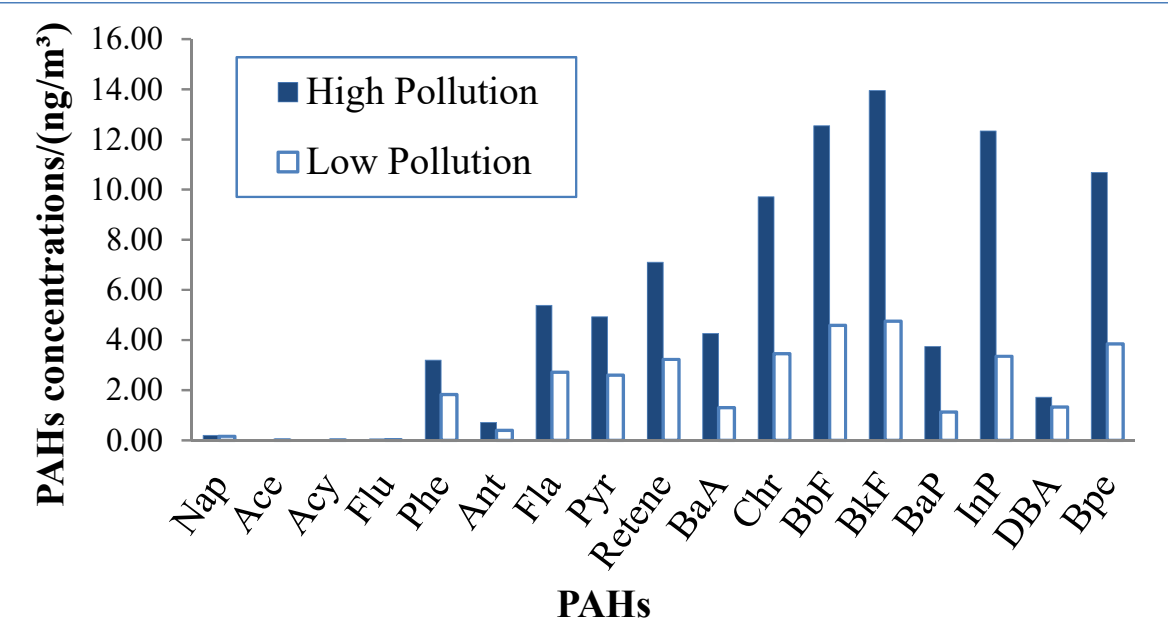

Fig. 4 Comparison of PAH concentrations in the high and low pollution periods 


\section{Table Captions}

843 Table 1 Average daily values for the meteorological data during the high and low pollution 844 periods

845 Table 2 Water soluble $(\mathrm{Cws})$ and total $\left(\mathrm{C}_{\mathrm{T}}\right)$ metal concentrations, corresponding water 846 solubility and enrichment factors (EF) of the high and low pollution samples

847 Table 3 Correlation matrix for the trace metal concentrations

848 Table 4 Average concentrations of ionic species and their abundance in $\mathrm{PM}_{2.5}$

849 Table 5 Average concentrations of levoglucosan and mannosan during the high and low 850 pollution periods

851 Table 6 Comparisons of chemical compositions and their relative abundance in highly 852 polluted aerosols from different regions in China 
853 Table 1 Average daily values for the meteorological data during the high and low pollution periods

\begin{tabular}{lcccccc}
\hline & $\begin{array}{c}\text { Sampling } \\
\text { Days }\end{array}$ & $\begin{array}{c}\mathrm{PM}_{2.5} /(\mu \mathrm{g} \\
\left.\mathrm{m}^{-3}\right)\end{array}$ & $\begin{array}{c}\text { Temperature } \\
\left({ }^{\circ} \mathrm{C}\right)\end{array}$ & $\begin{array}{c}\text { Rainfall } \\
(\mathrm{mm})\end{array}$ & $\begin{array}{c}\text { Wind Speed } \\
(\mathrm{km} / \mathrm{h})\end{array}$ & $\begin{array}{c}\text { Relative } \\
\text { Humidity }(\%)\end{array}$ \\
\hline High Pollution & 18 & $110.9 \pm 30.8$ & 6.5 & 0.015 & 2.1 & 67.9 \\
Low Pollution & 14 & $52.6 \pm 11.9$ & 18.8 & 0.040 & 1.9 & 76.8 \\
\hline
\end{tabular}

854 
855 Table 2 Water soluble $\left(\mathrm{C}_{\mathrm{WS}}\right)$ and total $\left(\mathrm{C}_{\mathrm{T}}\right)$ metal concentrations, corresponding water solubility and enrichment 856 factors $(\mathrm{EF})$ of the high and low pollution samples

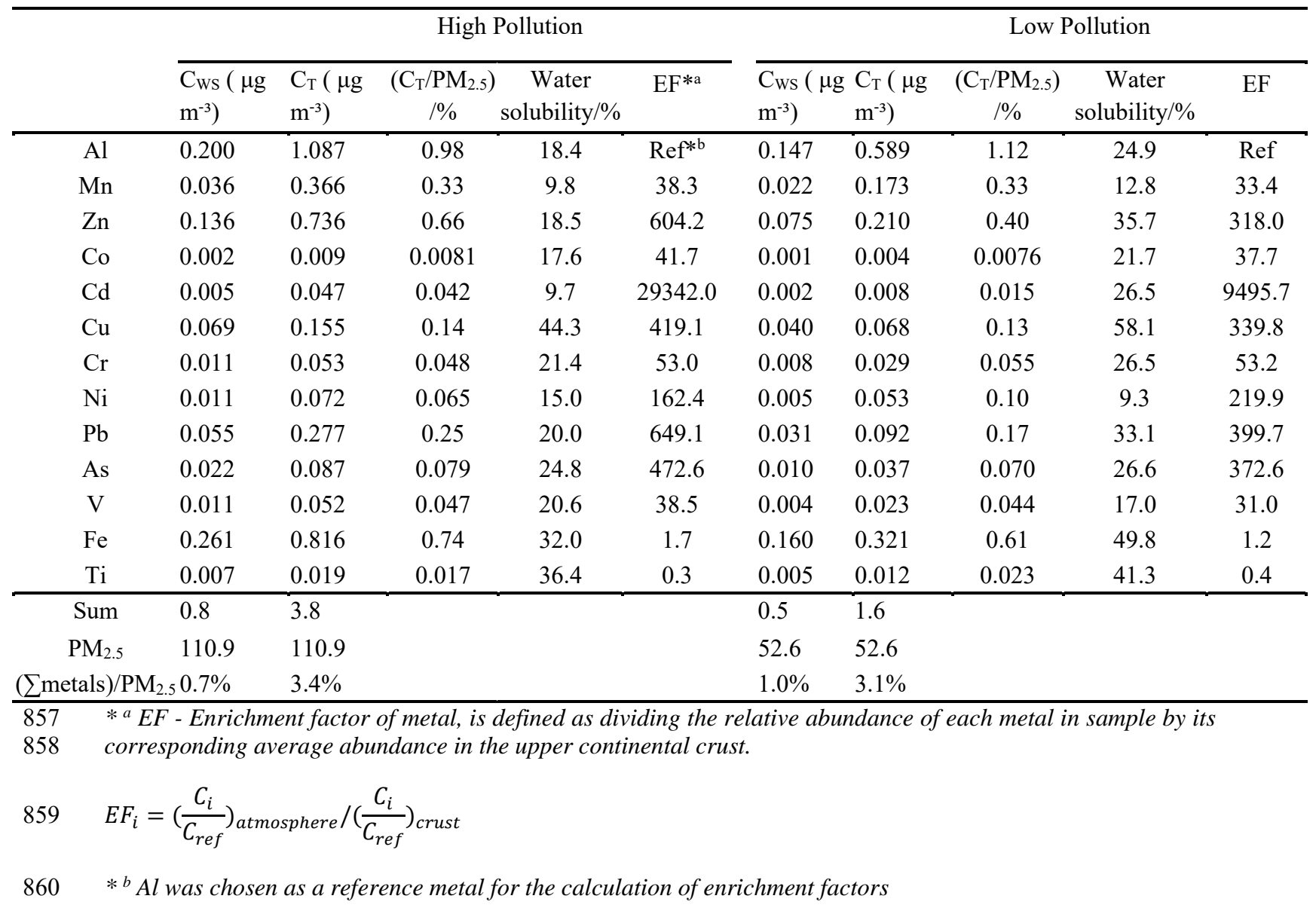


Table 3 Correlation matrix for the trace metal concentrations

\begin{tabular}{|c|c|c|c|c|c|c|c|c|c|c|c|c|c|}
\hline & $\mathrm{Mn}$ & $\mathrm{Zn}$ & $\mathrm{Co}$ & $\mathrm{Cd}$ & $\mathrm{Cu}$ & $\mathrm{Al}$ & $\mathrm{Cr}$ & $\mathrm{Ni}$ & $\mathrm{Pb}$ & As & $\mathrm{V}$ & $\mathrm{Fe}$ & $\mathrm{Ti}$ \\
\hline \multicolumn{14}{|c|}{ High Pollution } \\
\hline$\overline{\mathrm{Mn}}$ & 1 & & & & & & & & & & & & \\
\hline $\mathrm{Zn}$ & 0.4069 & 1 & & & & & & & & & & & \\
\hline $\mathrm{Co}$ & 0.2748 & 0.6224 & 1 & & & & & & & & & & \\
\hline $\mathrm{Cd}$ & 0.6139 & 0.4107 & 0.3286 & 1 & & & & & & & & & \\
\hline $\mathrm{Cu}$ & 0.5289 & 0.1341 & 0.4003 & 0.5093 & 1 & & & & & & & & \\
\hline $\mathrm{Al}$ & 0.0061 & 0.1871 & 0.3222 & 0.1075 & 0.0218 & 1 & & & & & & & \\
\hline $\mathrm{Cr}$ & 0.8803 & 0.4436 & 0.2122 & 0.4824 & 0.3332 & 0.0236 & 1 & & & & & & \\
\hline $\mathrm{Ni}$ & 0.4433 & 0.1323 & 0.2142 & 0.0872 & 0.5352 & 0.0059 & 0.3524 & 1 & & & & & \\
\hline $\mathrm{Pb}$ & 0.6618 & 0.3397 & 0.2772 & 0.9581 & 0.5257 & 0.0327 & 0.4959 & 0.1012 & 1 & & & & \\
\hline As & 0.8351 & 0.5981 & 0.3306 & 0.7216 & 0.4179 & 0.0110 & 0.7222 & 0.3050 & 0.6976 & 1 & & & \\
\hline $\mathrm{V}$ & 0.8470 & 0.3951 & 0.2354 & 0.5305 & 0.4756 & 0.0236 & 0.6940 & 0.4341 & 0.5678 & 0.9029 & 1 & & \\
\hline $\mathrm{Fe}$ & 0.8082 & 0.6936 & 0.363 & 0.7463 & 0.3254 & 0.0145 & 0.7202 & 0.186 & 0.7337 & 0.9477 & 0.8126 & 1 & \\
\hline $\mathrm{Ti}$ & 0.7885 & 0.4903 & 0.334 & 0.6958 & 0.5649 & 0.0209 & 0.6418 & 0.440 & 0.6583 & 0.948 & 0.8828 & 0.8173 & 1 \\
\hline \multicolumn{14}{|c|}{ Low Pollution } \\
\hline$\overline{\mathrm{Mn}}$ & 1 & & & & & & & & & & & & \\
\hline $\mathrm{Zn}$ & 0.0078 & 1 & & & & & & & & & & & \\
\hline Co & 0.2630 & 0.0530 & 1 & & & & & & & & & & \\
\hline $\mathrm{Cd}$ & 0.0194 & 0.0005 & 0.5251 & 1 & & & & & & & & & \\
\hline $\mathrm{Cu}$ & 0.2443 & 0.0008 & 0.5907 & 0.4194 & 1 & & & & & & & & \\
\hline $\mathrm{Al}$ & 0.2297 & 0.2543 & 0.4380 & 0.4679 & 0.5528 & 1 & & & & & & & \\
\hline $\mathrm{Cr}$ & 0.6450 & 0.2871 & 0.3748 & 0.1072 & 0.4597 & 0.0124 & 1 & & & & & & \\
\hline $\mathrm{Ni}$ & 0.5568 & 0.0179 & 0.8301 & 0.2303 & 0.5075 & 0.4323 & 0.1926 & 1 & & & & & \\
\hline $\mathrm{Pb}$ & 0.0024 & 0.0023 & 0.5275 & 0.6891 & 0.1763 & 0.2760 & 0.1086 & 0.2663 & 1 & & & & \\
\hline As & 0.0365 & 0.4745 & 0.0576 & 0.2961 & 0.2480 & 0.7264 & 0.0250 & 0.0398 & 0.0504 & 1 & & & \\
\hline $\mathrm{V}$ & 0.0130 & 0.0434 & 0.1481 & 0.0064 & 0.0011 & 0.1111 & 0.1882 & 0.1163 & 0.1847 & 0.5334 & 1 & & \\
\hline $\mathrm{Fe}$ & 0.0374 & 0.5416 & 0.1324 & 0.1731 & 0.1456 & 0.6172 & 0.0638 & 0.1527 & 0.2764 & 0.4387 & 0.0463 & 1 & \\
\hline $\mathrm{Ti}$ & 0.3469 & 0.2167 & 0.1670 & 0.0040 & 0.1763 & 0.0019 & 0.6092 & 0.1636 & 0.0063 & 0.0687 & 0.1229 & 0.2030 & 1 \\
\hline
\end{tabular}


863 Table 4 Average concentrations of ionic species and their abundance in $\mathrm{PM}_{2.5}$

\begin{tabular}{|c|c|c|c|c|c|}
\hline & \multicolumn{2}{|c|}{ High Pollution } & \multicolumn{2}{|c|}{ Low Pollution } & \multirow{2}{*}{$\begin{array}{c}\mathrm{C}_{\text {ion }}(\text { High Pollution }) / \\
\mathrm{C}_{\text {ion }}(\text { Low Pollution })\end{array}$} \\
\hline & $\mathrm{C}_{\text {ion }} * / \mathrm{ug} \mathrm{m}^{-3}$ & $\left(\mathrm{C}_{\text {ion }} / \mathrm{PM}_{2.5}\right) / \%$ & $\mathrm{C}_{\text {ion }} * / \mathrm{ug} \mathrm{m}^{-3}$ & $\left(\mathrm{C}_{\text {ion }} / \mathrm{PM}_{2.5}\right) / \%$ & \\
\hline $\mathrm{F}^{-}$ & 0.06 & 0.06 & 0.05 & 0.09 & 1.37 \\
\hline $\mathrm{Cl}^{-}$ & 3.32 & 3.09 & 2.44 & 4.65 & 1.36 \\
\hline $\mathrm{Br}^{-}$ & 0.013 & 0.01 & 0.007 & 0.01 & 1.78 \\
\hline $\mathrm{NO}_{3}^{-}$ & 12.39 & 11.51 & 5.93 & 11.27 & 2.09 \\
\hline $\mathrm{SO}_{4}^{2-}$ & 27.08 & 25.16 & 14.65 & 27.86 & 1.85 \\
\hline $\mathrm{Li}^{+}$ & 0.06 & 0.06 & 0.05 & 0.10 & 1.20 \\
\hline $\mathrm{Na}^{+}$ & 4.37 & 4.06 & 3.42 & 6.50 & 1.28 \\
\hline $\mathrm{NH}_{4}^{+}$ & 7.15 & 6.64 & 2.67 & 5.07 & 2.68 \\
\hline $\mathrm{K}^{+}$ & 1.56 & 1.45 & 0.77 & 1.46 & 2.04 \\
\hline $\mathrm{Mg}^{2+}$ & 0.84 & 0.78 & 0.57 & 1.08 & 1.48 \\
\hline $\mathrm{Ca}^{2+}$ & 2.61 & 2.43 & 2.07 & 3.93 & 1.27 \\
\hline sum & 59.5 & 55.3 & 32.6 & 62.0 & - \\
\hline
\end{tabular}

$864 * C_{i o n}$ was defined as the average value of daily mean ionic concentration during high/low pollution episode. 
865 Table 5 Average concentrations of levoglucosan and mannosan during the high and low pollution periods

\begin{tabular}{rccc}
\hline & Levoglucosan $/\left(\mathrm{ng} \mathrm{m}^{-3}\right)$ & Mannosan $/\left(\mathrm{ng} \mathrm{m}^{-3}\right)$ & $\mathrm{L} / \mathrm{M}$ \\
\hline High Pollution & $76.1 \pm 27.7$ & $14.9 \pm 6.3$ & 5.2 \\
Low Pollution & $14.7 \pm 6.7$ & $2.6 \pm 1.4$ & 5.9 \\
\hline
\end{tabular}


Table 6 Comparisons of chemical compositions and their relative abundance in highly polluted aerosols from different regions in China

\begin{tabular}{|c|c|c|c|c|c|c|c|}
\hline Location & $\begin{array}{l}\text { Sampling period } \\
\text { (yyyy/mm-yyyy/mm) }\end{array}$ & $\mathrm{PM}_{2.5}\left(\mu \mathrm{g} \mathrm{m}^{-3}\right)$ & Metals $\left(\mu \mathrm{g} \mathrm{m}^{-3}\right)$ & PAHs $\left(\right.$ ng m $\left.^{-3}\right)$ & $\begin{array}{l}\text { Inorganic ions } \\
\qquad\left(\mu \mathrm{g} \mathrm{m}^{-3}\right)\end{array}$ & $\begin{array}{l}\text { Levoglucosan } \\
\quad\left(\mathrm{ng} \mathrm{m}^{-3}\right)\end{array}$ & Reference \\
\hline Ningbo, YRD region & 2012/12-2013/01 & $110.9 \pm 30.8$ & $3.78\left(3.4 \%{ }^{* 1}\right)$ & $90.6(0.8 \%)$ & $59.5(55.3 \%)$ & $76 \pm 28(0.7 \%)$ & This study \\
\hline Suzhou etc, YRD region & 2009-07/2010/04 & & & 88.2 & & & Zhang et al., 2013 \\
\hline Hangzhou, YRD region & 2004/04-2005/03 & $108.2 \pm 43.2$ & & & $41.7(38.5 \%)$ & & Liu et al., 2015 \\
\hline PRD region & 2010/11-2010/12 & & & $91.5 \pm 36.1$ & & & Huang et al., 2014 \\
\hline PRD region & $\begin{array}{l}\text { 2010/05-2010/06 } \\
2010 / 11-2010 / 12\end{array}$ & & & & & $181.0 \pm 124.0$ & Zhang et al., 2015b \\
\hline Beijing, Northern China & 2002/07-2003/07 & 99.2 & & & & $307(3.1 \%)$ & Zhang et al., 2008 \\
\hline Tianjin, Northern China & 2013/01-2013/01 & $>94$ & & & & & Han et al., 2014 \\
\hline Handan, Northern China & 2012/12-2013/01 & $160.1 \pm 77.9$ & & & $77.3(48.3 \%)$ & & Wei et al., 2014 \\
\hline Zhengzhou, Northern China & 2011/03-2014/01 & $194 \pm 109$ & & $211(1.1 \%)$ & & & Wang et al., 2015a \\
\hline Beijing, Northern China & 2006/12-2006/12 & $142.3 \pm 46.0$ & $3.74(2.6 \%)$ & & $50.9\left(\mathrm{SNA}^{* 2}\right)$ & & Tan et al., 2016 \\
\hline Beijing, Northern China & 2013/01-2013/02 & $258 \pm 100$ & & & 116.5 (SNA) & $359.3 \pm 130.2$ & Ho et al., 2016 \\
\hline Xi'an, Central China & 2013/01-2013/02 & $233 \pm 52$ & & & 125.6 (SNA) & $653.3 \pm 191.4$ & Ho et al., 2016 \\
\hline
\end{tabular}

${ }^{{ }_{1} 1}$ Percentages in the table are the relative abundance of each chemical component in $\mathrm{PM}_{2.5}$, calculated as its mass concentration divided by its corresponding PM ${ }_{2.5}$

$869{ }^{* 2} \mathrm{SNA}-\mathrm{SO}_{4}{ }^{2-}, \mathrm{NO}_{3}^{-}$and $\mathrm{NH}_{4}^{+}$(namely SNA) 